\title{
Mechanisms of Glutamate Metabolic Signaling in Retinal Glial (Müller) Cells
}

\author{
Serge Poitry, ${ }^{1}$ Carol Poitry-Yamate, ${ }^{1}$ Joern Ueberfeld, ${ }^{2}$ Peter R. MacLeish, ${ }^{3}$ and Marcos Tsacopoulos ${ }^{1}$ \\ ${ }^{1}$ Department of Physiology, University of Geneva Medical School, 1211 Geneva 4, Switzerland, ${ }^{2}$ Department of Applied \\ Physics, University of Geneva, 1211 Geneva 4, Switzerland, and ${ }^{3}$ Neuroscience Institute, Morehouse School of Medicine, \\ Atlanta, Georgia 30310-1495
}

Retinal Müller (glial) cells metabolize glucose to lactate, which is preferentially taken up by photoreceptor neurons as fuel for their oxidative metabolism. We explored whether lactate supply to neurons is a glial function controlled by neuronal signals. For this, we used subcellular fluorescence imaging and either amperometric or optical biosensors to monitor metabolic responses simultaneously from mitochondrial and cytosolic compartments of individual Müller cells from salamander retina. Our results demonstrate that lactate production and release is controlled by the combined action of glutamate and $\mathrm{NH}_{4}{ }^{+}$, both at micromolar concentrations. Transport of glutamate by a highaffinity carrier can produce in Müller cells a rapid rise of glutamate concentration. In our isolated Müller cells, glutamine synthetase (GS) converted transported glutamate to glutamine that was released. This reaction, predominant when enough $\mathrm{NH}_{4}{ }^{+}$ is available, was limited at micromolar concentrations of $\mathrm{NH}_{4}{ }^{+}$,

There is experimental evidence suggesting the existence of lactate trafficking from astrocytes to neurons (for review, see Tsacopoulos and Magistretti, 1996). For example, lactate transport across the cytoplasmic membrane of astrocytes and neurons was shown to be mediated by cell type-specific monocarboxylate transporters (Bröer et al., 1997; Pellerin et al., 1998), but probably the most convincing evidence to date for such trafficking and utilization of lactate as fuel by neurons was provided by quantitative studies on the metabolic fate of glucose in retinal cells. Indeed, Poitry-Yamate et al. (1995) found that acutely isolated Müller cells metabolize glucose to synthesize and release large amounts of lactate. This lactate, in turn, is taken up by photoreceptor neurons and serves as the preferred fuel for oxidative metabolism. Moreover, because the metabolism of glucose and glycogen in Müller cells was modulated by light absorbed by the visual pigment of the photoreceptors, it appears that these two cells function as metabolically coupled units and that there is a

\footnotetext{
Received Aug. 3, 1999; revised Dec. 16, 1999; accepted Dec. 22, 1999.

This work was supported by Swiss National Science Foundation Grant 3150893.97, the Sandoz Foundation for Advancement of Biomedical Sciences, the Swiss Foundation for Fight against Blindness, the Hans Wilsdorf Foundation, the MEDIC Foundation, and National Institutes of Health Grant NS35510 (P.R.M.). We thank Dr. J. B. Clark (University College, London) for critical comments, Dr. K. Do and B. Benz (Centre de Recherche en Neurosciences Psychiatriques, PrillyLausanne) for HPLC measurements, and P. Perrottet for expert technical assistance.

Correspondence should be addressed to Marcos Tsacopoulos, Centre Médical Universitaire, 1 rue Michel-Servet, 1211 Geneva 4, Switzerland. E-mail: Marcos. Tsacopoulos@medecine.unige.ch.

Copyright (C) 2000 Society for Neuroscience $\quad 0270-6474 / 00 / 201809-13 \$ 15.00 / 0$
}

and more glutamate entered then as substrate into the mitochondrial tricarboxylic acid cycle (TCA). Increased production of glutamine by GS leads to increased utilization of ATP, some of which is generated glycolytically. Methionine sulfoximine, a specific inhibitor of GS, suppressed the stimulatory effect of glutamate and $\mathrm{NH}_{4}{ }^{+}$on glycolysis and induced massive entry of glutamate into the TCA cycle. The rate of glutamine production also determined the amount of pyruvate transaminated by glutamate to alanine. Lactate, alanine, and glutamine can be taken up and metabolized by photoreceptor neurons. We conclude that a major function of Müller glial cells is to nourish retinal neurons and to metabolize the neurotoxic ammonia and glutamate.

Key words: ammonia; glutamine synthetase; biosensor; $\mathrm{NADH}$; fluorescence imaging; lactate; retina

signal controlling the transfer of substrates from glial cells to neurons.

In the honeybee retina, the exact signaling mechanism has been recently elucidated (Tsacopoulos et al., 1997a,b): functioning photoreceptor neurons produce and release, in a stimulusdependent manner, $\mathrm{NH}_{4}{ }^{+}$and glutamate which, in turn, are transported into glia. A stimulus-induced transient rise in the intraglial concentration of $\mathrm{NH}_{4}{ }^{+}$and glutamate caused a net activation of glycolysis by a direct and synchronous action on three enzymatic reactions. These clear findings are possibly of interest to vertebrate studies. Indeed, glutamate is the predominant excitatory neurotransmitter in the mammalian retina and brain, and it has been shown that glutamate stimulates the uptake and phosphorylation of glucose and increases the amount of lactate released by cultured astrocytes (Pellerin and Magistretti, 1994). However, the exact metabolic signaling mechanism of glutamate has not been established in vertebrates because glutamate transported into astrocytes is known to participate as a substrate in several reactions that occur in the cytosol or in the mitochondria (Cooper and Plum, 1987; for review, see Schousboe et al., 1997), and there was no model of extreme metabolic compartmentation equivalent to the honeybee retina. We explored metabolic signaling in acutely isolated Müller glial cells from the salamander retina because they present this high degree of metabolic compartmentation. Indeed, mitochondria are found almost exclusively in the distal processes, located in the retina near the glutamatergic synaptic terminal of photoreceptors (Tsacopoulos et al., 1998, their Fig. 5b). This feature permitted the use of novel techniques to monitor metabolic responses from 
metabolically different regions of solitary Müller cells. Here we show that glutamate, in coordination with $\mathrm{NH}_{4}{ }^{+}$, exerts a strong activation of glycolysis via the glutamine synthetase reaction. As a result, the production and release of lactate, glutamine, and alanine by these glial cells are modulated to meet, presumably, the requirements of the functioning neurons. We believe that this evidence provides a basis for interpreting the observed coupling between brain activity and metabolism (Magistretti et al., 1999).

\section{MATERIALS AND METHODS}

Materials. Papain was purchased from Worthington (Freehold, NJ), and neutral glutaminase from Applied Enzyme Technology (Leeds, UK). 2,7-Biscarboxyethyl-5(6)-carboxyfluorescein-AM (BCECF-AM) and 5-carboxy-4',5'-dimethylfluorescein (CDMF) were obtained from Molecular Probes (Leiden, The Netherlands). Amytal (amobarbital) sodium was from Serva Feinbiochemica (Heidelberg, Germany). All other chemicals were purchased from Sigma (Buchs, Switzerland).

Preparation of Müller cells isolated from the salamander retina. Tiger salamanders (Ambystoma tigrinum) were purchased from Charles Sullivan (Nashville, TN) and were kept in a tank filled with tap water maintained at $10^{\circ} \mathrm{C}$. The procedure for cell isolation followed that of MacLeish and Townes-Anderson (1988) with some modifications. Salamanders were decapitated and pithed. Eyes were enucleated and transsected, and the retinas were removed and placed in an enzyme solution that contained (in mM): $112 \mathrm{NaCl}, 3 \mathrm{KCl}, 0.1 \mathrm{CaCl}_{2}, 0.1 \mathrm{MgCl}_{2}$, $0.5 \mathrm{NaH}_{2} \mathrm{PO}_{4}, 1 \mathrm{NaHCO}_{3}, 0.1$ choline- $\mathrm{Cl}, 16$ glucose, 10 HEPES, and 5 cysteine- $\mathrm{HCl}$, and $0.001 \%$ phenol red and $\sim 15 \mathrm{U} / \mathrm{ml}$ papain, $\mathrm{pH}$ 6.4. The activity of the enzyme solution was routinely checked before use by measuring the rate of acid production from benzoyl-L-arginine ethyl ester (see Worthington Manual). The $16 \mathrm{~mm}$ glucose concentration in the enzyme solution was to provide the retina with ample substrate during incubation. Retinas were incubated at $22-25^{\circ} \mathrm{C}$ with gentle agitation for $1 \mathrm{hr}$ (or more, depending on the activity of the enzyme) and then rinsed several times with a slightly hyperosmotic solution of similar composition, but without cysteine and papain, and with $32 \mathrm{~mm}$ sucrose added. Retinas were then gently triturated using a fire-polished Pasteur pipette previously treated with bovine serum albumin (BSA; $0.1 \mathrm{mg} / \mathrm{ml}$ ). Aliquots of the cell suspension were then placed onto a glass coverslip coated with salamander-specific antibody (Sal-1) serving as adhesion substrate for the cells (MacLeish et al., 1983; MacLeish and TownesAnderson, 1988). Coating of the coverslip was obtained by applying overnight $100 \mu$ l of goat affinity-purified antibody to mouse $\operatorname{IgG}(\mathrm{G} \alpha \mathrm{M}$; Cappel Research Products, Durham, NC) over the thoroughly cleaned glass surface and by adding then for $1 \mathrm{hr}$ before cell isolation, a $100 \mu \mathrm{l}$ sample of salt solution containing the Sal-1 antibody. Cells were left 30 min to adhere to the coverslip and were then covered with salamander Ringer's solution with the following composition (in $\mathrm{mM}$ ): $112 \mathrm{NaCl}, 3$ $\mathrm{KCl}, 1.8 \mathrm{CaCl}_{2}, 0.5 \mathrm{MgCl}_{2}, 0.5 \mathrm{MgSO}_{4}, 0.5 \mathrm{NaH}_{2} \mathrm{PO}_{4}, 1 \mathrm{NaHCO}_{3}, 0.1$ choline-Cl, 0.5 glucose, and 10 HEPES and $0.001 \%$ phenol red, pH 7.4. This concentration of glucose in normal Ringer's solution is close to the extracellular concentration measured in rat striatum (Lowry et al., 1998) and was intended to mimic the extracellular concentration in the retina, which has not yet been measured. To maintain cells as long as possible, and because larval tiger salamanders are poikilotherms living in cool water, dissociated cells were maintained at $17^{\circ} \mathrm{C}$, before and during the experiment.

Purified Müller cell islands. The procedure was similar to the general procedure described above, with a few modifications. First, only droplets of $\mathrm{G} \alpha \mathrm{M}$ coating (see above) were deposited onto the surface of the glass coverslip; when dried, these produced islands $300-800 \mu \mathrm{m}$ in diameter that were then covered with $100 \mu \mathrm{l}$ of Sal-1 solution. Müller cells dissociated as described above were purified by gravity sedimentation through a column of salt solution carrying BSA (500 $\mu$ l of cell suspension on $500 \mu \mathrm{l}$ of $10 \%$ BSA-Ringer's solution, in an Eppendorf tube). After 20 min of sedimentation, a $300 \mu \mathrm{l}$ band of purified Müller cells was located and removed. These were allowed to settle on the island for $\sim 10$ min and were then rinsed several times with salamander Ringer's solution. Cellular debris remaining after purification and not adhering to the antibody were then washed away with medium. To obtain complete purification, in some experiments, cellular debris adhering to the Sal-1 antibody was removed by aspiration into a micropipette.

Fluorescence imaging of individual cells. Fluorescence was measured on an inverted Axiovert 135TV epifluorescence microscope (Carl Zeiss
AG, Feldbach, Switzerland) equipped with Zeiss Pan-Neofluar $63 \times$ oil immersion lens (1.25 numerical aperture) and fitted with a xenon arc lamp, interference and neutral density filters, and an electromagnetic shutter. Selected cells were positioned in the middle of the optical field, and puffer pipettes (tip diameter, $\sim 4 \mu \mathrm{m}$ ) containing the test solution were advanced to within $50 \mu \mathrm{m}$ from the central portion of the cell and remained in place for the duration of the experiment. Images, obtained by collecting fluorescence for $200 \mathrm{msec}$, were captured every $3 \mathrm{sec}$ with a video CCD camera (Photonic Science, Robertsbridge, UK) and processed by Ion Vision Software (ImproVision, Coventry, UK) on a Power Macintosh 8100/100AV computer. Some data were obtained on another setup, equipped with an Eclipse TE300-DV microscope (Nikon AG, Küsnacht, Switzerland), a Nikon Plan Fluor 100× oil immersion lens (1.3 numerical aperture), a monochromator (T.I.L.L. Photonics, Planegg, Germany), a cooled intensified CCD camera (Photonic Science), Openlab software (ImproVision), and a Power Macintosh 9600/350 computer. The NAD $(\mathrm{P}) \mathrm{H}$ traces presented in Figure 4 were recorded with another cooled CCD camera (Photometrics Ltd, Tuscon, AZ), as described in Tsacopoulos et al. (1998). For $\mathrm{pH}_{\mathrm{i}}$ measurements, cells were exposed for $5 \mathrm{~min}$ to BCECF-AM $(2.5 \mu \mathrm{g} / \mathrm{ml})$. After washout of extracellular dye, $\mathrm{pH}_{\mathrm{i}}$ was measured from the ratio of light emitted near $550 \mathrm{~nm}$ on excitation at 490 and at $440 \mathrm{~nm}$. For NAD(P)H fluorescence, excitation was at $360 \mathrm{~nm}$, and light emitted between 450 and $490 \mathrm{~nm}$ was collected; we refer to this fluorescence as "NAD $(\mathrm{P}) \mathrm{H}$ fluorescence", meaning "the sum of NADH and NADPH fluorescence", because the fluorescence of NADH cannot be distinguished from that of NADPH (Barbour et al., 1993). For FAD fluorescence, excitation was at $440 \mathrm{~nm}$, and light emitted between 515 and $565 \mathrm{~nm}$ was collected. Fluorescence of different compounds was measured sequentially (e.g., first NAD $(\mathrm{P}) \mathrm{H}$ imaging, then BCECF loading and imaging). A slight drift of the baseline was observed on the recordings of NAD $(\mathrm{P}) \mathrm{H}$ or FAD fluorescence. This drift, which was probably attributable to bleaching of the fluorophore, caused on average a signal decrease of $1.7 \pm 0.3 \%$ per min (estimation on 78 traces from 53 cells). To facilitate comparison between individual responses, all the data were corrected for baseline drift. For this, we calculated for each trace the average slope of the signal during the $30 \mathrm{sec}$ preceding stimulation and then subtracted the extrapolated baseline from the whole signal trace.

Lactate measurements. Lactate-sensitive microelectrodes (see Fig. 7A) consisted in glass-insulated platinum $(\mathrm{Pt})$ microelectrodes onto which a polymer layer immobilizing some lactate oxidase was deposited. The procedure for fabricating such microelectrodes has been described in detail (Cosnier et al., 1997; Poitry et al., 1997). Briefly, the tip of a glass micropipette was broken with a diamond cutter to an inner diameter of 20-40 $\mu \mathrm{m}$. A Pt wire [Pt 90\%, iridium (Ir) 10\%; $125 \mu \mathrm{m}$ diameter] was etched by electrolysis in saturated $\mathrm{KCN}$ solution until its tip diameter was only $2-5 \mu \mathrm{m}$. This Pt wire was then introduced into the micropipette and advanced until its tip protruded from the opening of the micropipette. Insulation of the Pt wire was obtained by gently melting the tip of the micropipette to produce a glass sleeve around the tip of the Pt wire. The excess Pt wire still protruding from the tip of the micropipette was then etched by electrolysis under a thin jet of $2 \mathrm{~m} \mathrm{NaCl}$ solution. Finally, a polypyrrole film in which lactate oxidase was immobilized was deposited onto the exposed Pt surface by electropolymerization. Lactate oxidase from Pedioccocus oxidizes L-lactate (but not D-lactate; Eichel and Rem, 1962; Naka, 1993) to pyruvate and hydrogen peroxide. The $\mathrm{pH}$ dependence of the reaction is weak, with an optimal pH of $\sim 7.5$ (Clark et al., 1984; Raba and Motola, 1994), and the $K_{\mathrm{m}}$ of the enzyme for L-lactate is $700 \mu \mathrm{M}$ (Sigma datasheet). The amperometric detection of L-lactate was achieved by holding the potential of the microelectrode at $+0.6 \mathrm{~V}$ relative to an $\mathrm{Ag}-\mathrm{AgCl}$ reference electrode to detect the hydrogen peroxide produced in the reaction. We previously used the same technique to make glutamate-sensitive microelectrodes based on the entrapment of glutamate oxidase, and the performance of this type of microelectrode has been described in detail (Cosnier et al., 1997; Poitry et al., 1997). The response of the microelectrodes used in the present study was linear in the range $0-50 \mu \mathrm{M} \mathrm{L}$-lactate, and it was not affected by $200 \mu \mathrm{M}$ alanine, glutamine, glutamate, or $\mathrm{NH}_{4} \mathrm{Cl}$ (Fig. 1); it was also not affected by possible $\mathrm{pH}$ changes induced by lactate released from the cells: the 10 mM HEPES buffer in our Ringer's solution was largely in excess of the concentration of lactate released, so that $\mathrm{pH}$ changes could not have exceeded $0.01 \mathrm{pH}$ unit in this study. The response times were always $<10$ sec. Microelectrodes kept at $4^{\circ} \mathrm{C}$ retained their sensitivity for up to 3 weeks. This type of microelectrode cannot be used for accurate measurements in cells and tissues releasing catecholamines or ascorbic acid 


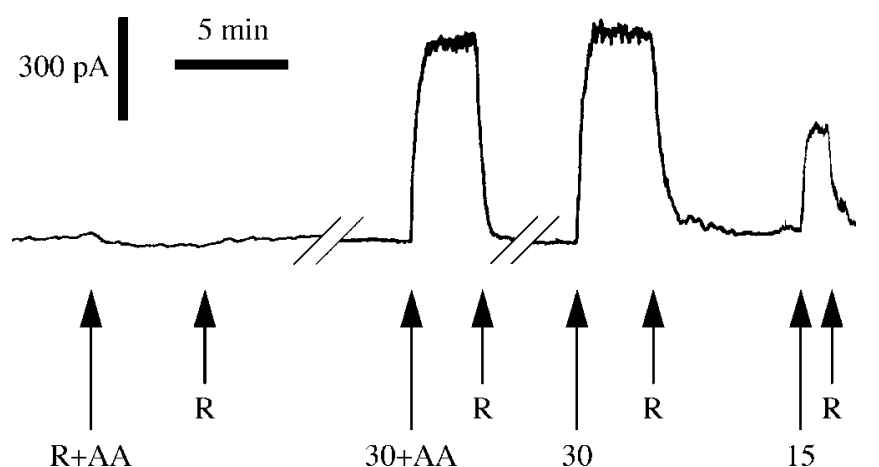

Figure 1. Current recording showing the sensitivity and the selectivity of the lactate sensor. Initially, the sensor was in Ringer's solution, and arrows indicate the times at which the sensor was exposed to new solution. $R$, Ringer's solution; $+A A$, + alanine + glutamine + glutamate $+\mathrm{NH}_{4} \mathrm{Cl}$ (200 $\mu \mathrm{M}$ each); 30 (or 15), Ringer's solution +30 (or 15) $\mu \mathrm{M}$ lactate.

(i.e., molecules that can be oxidized directly on the Pt surface), unless these interfering signals are subtracted. Control experiments with the same Pt microelectrode as used for lactate measurements, but without deposited enzyme, showed us that Müller cells do not release detectable amounts of directly oxidizable compounds. For this test, the old enzyme layer was removed from the Pt surface by briefly dipping the microelectrode in $1 \mathrm{M} \mathrm{HCl}$, followed by rinsing in distilled water and rapid electrolysis of the Pt surface in $2 \mathrm{~m} \mathrm{NaCl}$ solution.

Ammonia measurements. The ammonia sensor was made of a micropipette whose tip was filled with a droplet of fluorescent $\mathrm{pH}$ indicator covered with a gas-permeable membrane. This sensor is a miniaturized version of the sensor described by Kar and Arnold (1992). The method for fabricating this sensor was similar to that described by Elamari et al. (1997), with some modifications. A glass micropipette with short stem was made, using a vertical homemade puller, and its tip was broken with a diamond cutter to an inner diameter of $50 \mu \mathrm{m}$ and fire-polished. A Teflon membrane (standard $65 \mathrm{~N}$; DuPont de Nemours) was stretched and fitted over the opening of a $10 \mathrm{~mm}$ glass tube and then heated for 10 $\min$ at $300^{\circ} \mathrm{C}$. Then, the fire-polished micropipette was pushed through the heated membrane at its thinnest part, so that a membrane patch remained attached over the tip of the micropipette, thus closing the opening. This membrane was impermeable to water and ions, but permeable to gases. Only the stem of the micropipette, situated proximally to the Teflon-covered tip, was back-filled with a droplet of solution containing $115 \mathrm{~mm} \mathrm{NaCl}$ and $0.5 \mathrm{~mm} \mathrm{CDMF}$ indicator, $\mathrm{pH}$ 5.4. Unprotonated CDMF is fluorescent (peak excitation, $\sim 505 \mathrm{~nm}$; peak emission, $537 \mathrm{~nm}$ ), but the protonated CDMF is not. Because its $\mathrm{pK}_{\mathrm{a}}$ is close to 7, $\mathrm{CDMF}$ can be used as a fluorescent $\mathrm{pH}$ indicator from approximately $\mathrm{pH}$ 5-9. An optical fiber (120 $\mu$ m diameter; CeramOptech, Bonn, Germany) was then introduced into the micropipette by means of a specially constructed holder, so that the extremity of the fiber was positioned in the droplet as close as possible to the Teflon membrane. Thus, the volume of the solution trapped between the fiber end and the Teflon membrane was typically $<1 \mathrm{nl}$, and indicator fluorescence was monitored only in this minute volume. The other end of the optical fiber was connected to the collecting end of a multimode optical fiber coupler ( $\mathrm{Y}$ type, GI 100/140 $\mu \mathrm{m}, 0.29$ numerical aperture; Corning, Corning, NY). One arm of the optical fiber coupler received the light beam from a green LED (Sibalco, Basel, Switzerland) that passed through a $509 \mathrm{~nm}$ interference filter; this light, traveling down the optical fiber, excited the fluorescent solution trapped inside the sensor tip. The emitted fluorescence was collected by the same optical fiber and measured through the second arm of the optical fiber coupler; this emitted light passed through a $537 \mathrm{~nm}$ interference filter and was directed, via an optical fiber pigtail, to a single-photon counting module (SPCM-100 PQ; E G \& G, Vaudreuil, Canada) connected to a timer/counter board of data acquisition (CTM-05/A; Keithley Instruments S.A., Dübendorf, Switzerland). In principle, the sensor detects $\mathrm{pH}$-changing gas molecules such as $\mathrm{NH}_{3}$ or $\mathrm{CO}_{2}$. However, the signals generated by these molecules are opposite: $\mathrm{NH}_{3}$ causes alkalinization (and thus increased fluorescence) of the indicator, whereas $\mathrm{CO}_{2}$ produces acidification of the indicator. In addition, the detection efficiency of the sensor is much higher for $\mathrm{NH}_{3}$ than for $\mathrm{CO}_{2}$ : because the $\mathrm{pH}$ of the indicator solution is 5.4 and the $\mathrm{pK}_{\mathrm{a}}$ of ammonia is $9.15,99.98 \%$ of $\mathrm{NH}_{3}$ molecules entering the sensor react with $\mathrm{H}^{+}$in the indicator solution and are converted to $\mathrm{NH}_{4}{ }^{+}$; in contrast, the $\mathrm{pK}_{\mathrm{a}}$ of $\mathrm{CO}_{2}$-bicarbonate is 6.17 and therefore only $14.5 \%$ of the $\mathrm{CO}_{2}$ molecules entering the sensor are converted to bicarbonate and generate $\mathrm{H}^{+}$. To increase further the detection efficiency for $\mathrm{NH}_{3}$ in our experiments, all ammonia measurements were performed in HEPESbuffered Ringer's solution, with no added bicarbonate, and at $\mathrm{pH}$ 7.8: thus, only $2.3 \%$ of $\mathrm{CO}_{2}$-bicarbonate released by the cells was found as $\mathrm{CO}_{2}$ in the Ringer's, whereas $4.3 \%$ of ammonia released by the cells was found as $\mathrm{NH}_{3}$. Typically, the sensor signal measured for $5 \mu \mathrm{M} \mathrm{NH} \mathrm{N}_{4} \mathrm{Cl}$ in Ringer's at $\mathrm{pH} 7.8$ corresponded to an increase of $0.3 \mathrm{pH}$ unit in indicator $\mathrm{pH}$, close to the Teflon membrane. The integrity of the Teflon membrane, which is essential for proper functioning of the sensor, was continuously monitored via the sensor fluorescence signal: any leak through the membrane resulted immediately in indicator dilution and, therefore, in irreversible decrease of fluorescence.

Chromatographic analysis. HPLC analysis was performed in the laboratory of Dr. Kim Q. Do (Brain Research Institute, University of Zurich) using a Hewlett-Packard chromatograph (model 1090) combined with a variable autoinjector, a cooled $\left(4^{\circ} \mathrm{C}\right)$ autosampler, a programmable fluorescence detector (HP 1046A), and analytical Hyperchrome HPLC columns, $250 \times 4.6 \mathrm{~mm}$ (Bischoff, Leonberg, Germany) packed with Hypersil ODS $5 \mu \mathrm{m}$ (Shandon, Cheshire, UK). For further detail, see Do et al. (1995).

\section{RESULTS}

\section{Glutamate transport and signaling}

Experiments in which the transport of glutamate is monitored as transmembrane current (Brew and Attwell, 1987) or as intracellular $\mathrm{pH}$ change (Bouvier et al., 1992) indicate that the uptake has an apparent $K_{\mathrm{m}}$ of $\sim 20 \mu \mathrm{M}$ and is fast enough to cause a rapid rise in the intracellular concentration of glutamate (Barbour et al., 1993). As previously shown (Brew and Attwell, 1987; Tsacopoulos et al., 1998), the magnitude of the glutamate-induced inward current in salamander Müller cells is largest at the level of the distal processes and at the cell soma (Fig. 2A). In the intact retina, these are regions extending from the glutamatergic synapses between photoreceptors and bipolar cells, to near the glutamatergic synapses between bipolar and ganglion cells (Brew and Attwell, 1987, their diagram in Fig. 4). These are also regions where the analog of the excitatory amino acid transporter subtype EAAT1 is found in salamander Müller cells (Eliasof et al., 1998; see also Rauen et al., 1998, for similar results on the rat retina). Thus, after a puff application of 40-200 $\mu \mathrm{m}$ glutamate, the change in the intracellular concentration of glutamate is expected to be as large in the distal processes, where most mitochondria are found (Tsacopoulos et al., 1998, their Fig. 5B), as in the mitochondria-poor soma of the cell. The similarity in the time course of the glutamate-induced $\Delta \mathrm{pH}_{\mathrm{i}}$ measured in the distal processes and soma (Fig. $2 B$ ) is indeed consistent with this reasoning.

Because the metabolism of glutamate through the tricarboxylic acid (TCA) cycle is associated with the control of the cytosolic reoxidation of NADH (see Fig. 12, reaction 3; Dennis and Clark, 1978), we developed a technique for imaging NAD(P)H fluorescence (see Materials and Methods) at the subcellular level in single acutely isolated Müller cells. As shown in Figures $2 B$ and 3 , basal $\mathrm{NAD}(\mathrm{P}) \mathrm{H}$ fluorescence was much more intense in the distal processes than in either the soma or the endfoot, in sharp contrast to the distribution of the mostly cytosolic dye BCECF (Fig. 2B, pictures). This distribution of $\mathrm{NAD}(\mathrm{P}) \mathrm{H}$ fluorescence is consistent with the distribution of mitochondria: estimates based on Figure $5 B$ from Tsacopoulos et al. (1998) indicate that the number of mitochondria is 5-10 times higher in the distal processes than in the rest of the cell, and it is well known that, although the total concentration of pyridine nucleotides is at least 


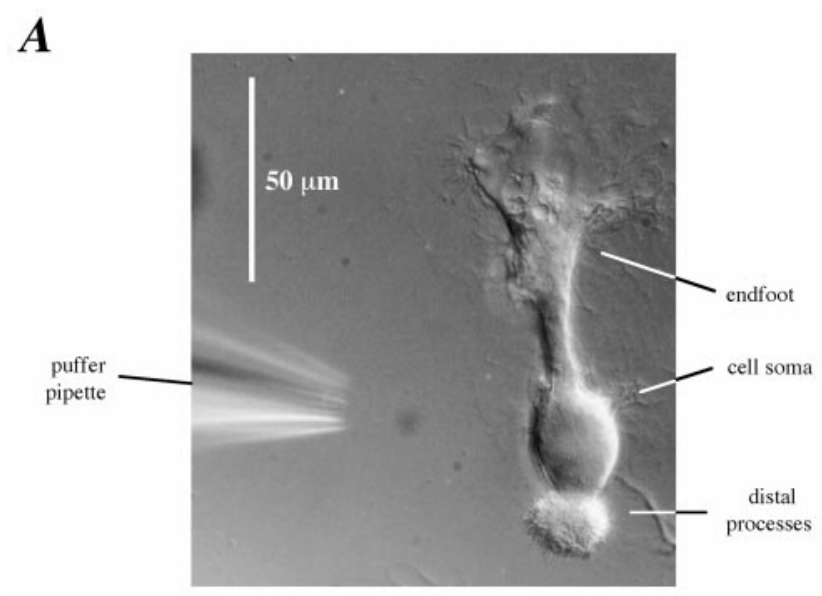

$\boldsymbol{B}$

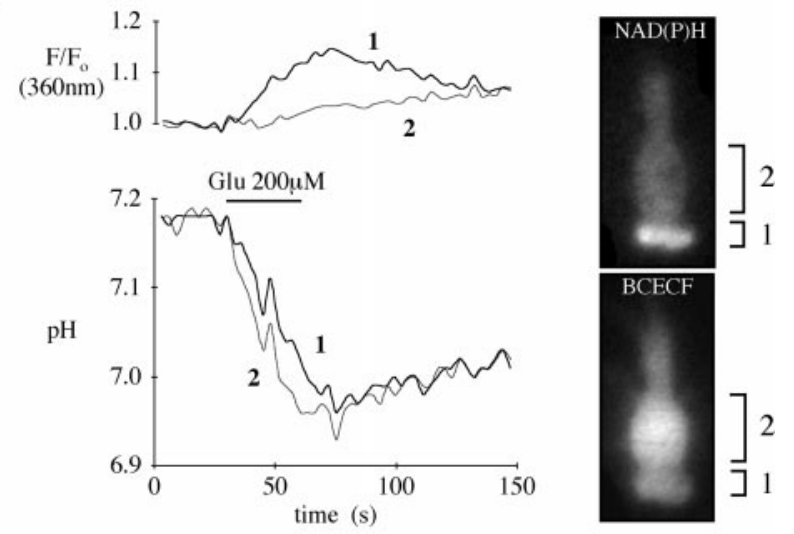

Figure 2. Effects on $\mathrm{pH}_{\mathrm{i}}$ and $\mathrm{NAD}(\mathrm{P}) \mathrm{H}$ fluorescence of pressure-ejecting glutamate $(200 \mu \mathrm{M})$ onto the surface of a Müller cell. $A$, Image of a freshly isolated salamander Müller cell plated in a Petri dish, showing the major specialized regions of the cell. In situ, the distal processes are in contact with synaptic terminals of photoreceptors. On the left and out of focus is shown a puffer pipette of the type we used in fluorescence measurements. $B$, Glutamate-induced transient acidification (bottom panel) in a Müller cell loaded with BCECF-AM. This acidification (Bouvier et al., 1992), occurs in the distal processes (trace 1), as well as in the soma (trace 2). In contrast, the glutamate-induced rise of $\mathrm{NAD}(\mathrm{P}) \mathrm{H}$ (top panel) occurs predominantly in the distal processes, but in parallel with that of $\Delta \mathrm{pH}_{\mathrm{i}}$. Note the different distribution of the fluorescence of $\mathrm{NAD}(\mathrm{P}) \mathrm{H}$ (top right) as compared to that of the mostly cytosolic dye BCECF (bottom right): $\mathrm{NAD}(\mathrm{P}) \mathrm{H}$ fluorescence is much higher in the distal processes (region 1) than in the soma (region 2) of the cell. These measurements were performed sequentially: $\mathrm{NAD}(\mathrm{P}) \mathrm{H}$ fluorescence was measured first, and then the cell was loaded with BCECF-AM and $\mathrm{pH}_{\mathrm{i}}$ was measured.

as high in mitochondria as in the cytosol, the redox ratio NADH/ $\mathrm{NAD}^{+}$is much higher in mitochondria than in cytosol (Sies, 1982). To test whether $\mathrm{NAD}(\mathrm{P}) \mathrm{H}$ fluorescence in the distal processes was indeed predominantly of mitochondrial origin, we puffed 3 mm of Amytal, a well established inhibitor of mitochondrial respiration (Ernster et al., 1955; Chance and Hess, 1959; Slater, 1967). As shown in Figure 3, $C$ and $D$, exposure of the cell for $30 \mathrm{sec}$ to Amytal caused a rapid and large $(>30 \%)$ increase of fluorescence restricted to the distal processes, in accordance with the hypothesis that the recorded fluorescence is predominantly mitochondrial and is mostly that of NADH (Sies, 1982, their Fig. $3 B$, Table 1).

Measurements performed on purified suspensions of acutely isolated Müller cells from the guinea pig retina have shown that the intracellular concentration of glutamate $(\sim 1 \mathrm{~mm}$; PoitryYamate et al., 1995) is much lower than in the whole retina. Under similar conditions, i.e., acutely isolated Müller cells bathed in a simple Ringer's solution, we tested whether glutamate modulates NAD(P)H fluorescence. Puffing either 40 or $200 \mu \mathrm{M}$ of glutamate for $30 \mathrm{sec}$ onto a Müller cell caused a transient monophasic increase of this fluorescence (54 cells), of similar amplitude for both concentrations, occurring mostly in the distal processes (Fig. 2B). These results are similar to those obtained by Barbour et al. (1993) who dialyzed salamander Müller cells with patch-clamp pipettes (see Discussion). In the first $2 \mathrm{hr}$ after cell isolation, we sometimes recorded a small biphasic response (18 cells) or a small monophasic decrease (26 cells) of NAD(P)H fluorescence in response to glutamate application. The same variability in response shape was seen when the cells were bathed in $16 \mathrm{~mm}$ glucose. Therefore, to ensure that the cells tested were all in a similar metabolic state, we decided in the following experiments to test cells $2-5 \mathrm{hr}$ after their acute isolation, i.e., when they all respond to glutamate by an increase in $\mathrm{NAD}(\mathrm{P}) \mathrm{H}$ fluorescence.

This glutamate-induced increase of mitochondrial NADH appears to be a typically glial response. Indeed, in the experiment shown in Figure 4, we made a simultaneous recording of $\mathrm{NAD}(\mathrm{P}) \mathrm{H}$ fluorescence from a glial Müller cell and from the ellipsoid of a closely located rod (the ellipsoid of a rod is packed with mitochondria; Townes-Anderson et al., 1985). Glutamate induced in the rod a small transient decrease of the fluorescence, whereas in the Müller cell the response was a large rise. Because salamander rod photoreceptors can also take up glutamate (Grant and Werblin, 1996), probably via transporters present near their synaptic terminal (Eliasof et al., 1998), this suggests that, in the same nervous tissue, the mitochondria in a neuron metabolize glutamate differently from those in a glial cell.

It has been shown that glutamate transporters transport also Land D-aspartate, and by the same ionic mechanism (Kanai and Hediger, 1992; Barbour et al., 1993). To test whether the glutamate-induced $\mathrm{NAD}(\mathrm{P}) \mathrm{H}$ response in the Müller cell was attributable to a specific action of glutamate or to the ionic current accompanying transport, we compared the effect of puffing glutamate to that of puffing L- or D-aspartate at the same concentration. As shown in Figure 5, the nonmetabolizable D-aspartate exerted a small effect, opposite that of L-glutamate on the same cells; L-aspartate also exerted an effect opposite that of glutamate, inducing a small decrease of $\mathrm{NAD}(\mathrm{P}) \mathrm{H}$ in all cells tested. In the experiment of Barbour et al. (1993), exposure of patch-dialyzed Müller cells to L- or D-aspartate induced an inward current, but had no effect on NAD(P)H. Taken together, these results strongly suggest that the $\mathrm{NAD}(\mathrm{P}) \mathrm{H}$ response to glutamate was attributable predominantly to a specific action of glutamate on the mitochondrial metabolism of the Müller cell. Therefore, we explored further the mechanisms underlying this effect.

Biochemical data obtained initially by Haslam and Krebs (1963) and extended later by Dennis and Clark $(1977,1978)$ show that, in mitochondria of probably mostly astrocytic origin and at millimolar concentrations of glutamate, $>70 \%$ of the glutamate entering the TCA cycle is oxidized through transamination with oxaloacetate. Aspartate and $\alpha$-ketoglutarate are released from these mitochondria into the cytosol where aspartate can be converted back to oxaloacetate and then malate, which reenters the mitochondria (see Fig. 12). This malate-aspartate shuttle, which contributes to the continual reoxidation of cytosolic NADH produced by glycolysis, occurs probably also in the Müller cell, 
$\boldsymbol{A}$

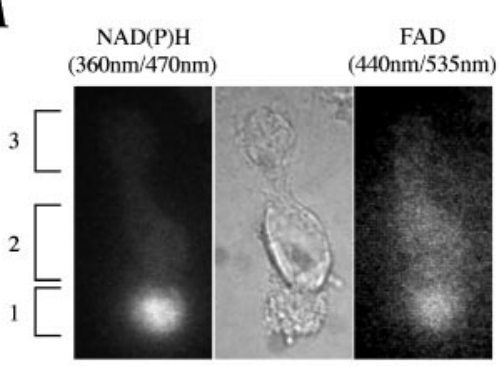

B

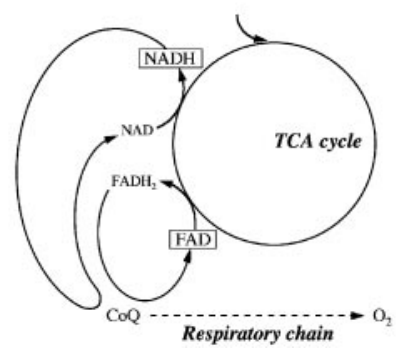

C

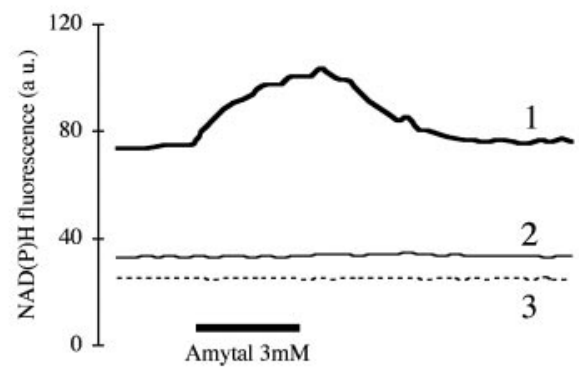

D

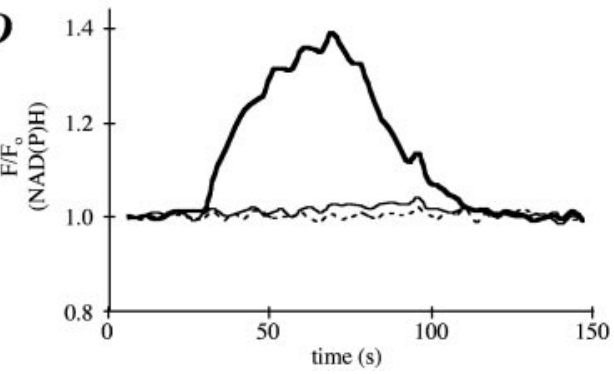

Figure 3. Relation of $\mathrm{NAD}(\mathrm{P}) \mathrm{H}$ fluorescence and FAD fluorescence to mitochondrial metabolism. $A$, Both types of fluorescence are observed predominantly in the distal processes of freshly isolated Müller cells, where mitochondria are packed (Tsacopoulos et al., 1998). Peak wavelengths of fluorescence excitation and of measured emission are given in parentheses. Compartmentation of fluorescence is more apparent for $\mathrm{NAD}(\mathrm{P}) \mathrm{H}$ than for FAD mainly because the fluorescence intensity of FAD is much lower (Masters and Chance, 1993). B, Schematic representation showing how the mitochondrial redox potential is linked to the functioning of the tricarboxylic acid cycle (TCA) and to respiration. Boxes indicate which member of each redox couple is fluorescent. $C$, Pressure-ejecting the inhibitor of mitochondrial respiration Amytal (3 mm; solid bar) onto a Müller cell induced a rapid rise of $\mathrm{NAD}(\mathrm{P}) \mathrm{H}$ fluorescence only in region 1 (top left panel), which corresponds to the distal processes of the cell. a.u., Arbitrary units. D, Same recordings as in $C$, but represented as relative changes, to show that the absence of $\mathrm{NAD}(\mathrm{P}) \mathrm{H}$ response from regions 2 and 3 is not attributable to the lower level of fluorescence.

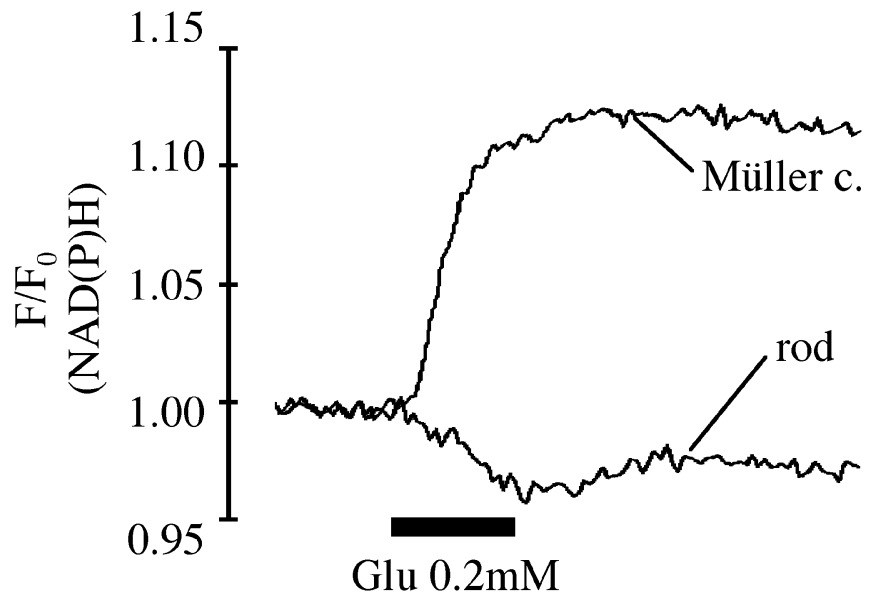

Figure 4. Comparison of the $\mathrm{NAD}(\mathrm{P}) \mathrm{H}$ fluorescence change induced by glutamate $(200 \mu \mathrm{M})$ in a freshly isolated Müller cell and in a rod. Although pressure ejection of glutamate induced a monophasic rise of $\mathrm{NAD}(\mathrm{P}) \mathrm{H}$ fluorescence in the distal processes of a Müller cell, the same pressure ejection induced a small transient decrease of $\mathrm{NAD}(\mathrm{P}) \mathrm{H}$ fluorescence in a neighboring rod inner segment, also packed with mitochondria. This indicates that the response of mitochondria to glutamate depends on their environment. The $30 \mathrm{sec}$ period during which the cell was exposed to glutamate is shown by the thick solid line.

because acutely isolated Müller cells metabolizing ${ }^{14} \mathrm{C}(\mathrm{U})$ glucose produce large amounts of ${ }^{14} \mathrm{C}$-aspartate (Poitry-Yamate et al., 1995), and also ${ }^{14} \mathrm{C}$-malate and ${ }^{14} \mathrm{C}$ - $\alpha$-ketoglutarate (PoitryYamate, 1994). However, because aspartate and $\alpha$-ketoglutarate are also released from Müller cells, the TCA cycle in these cells must be supplied with new intermediates through an anaplerotic process, to avoid depletion. Among such processes are the deamination of glutamate to $\alpha$-ketoglutarate by mitochondrial glutamate dehydrogenase (GDH), or the carboxylation of pyruvate to oxaloacetate by the glial enzyme pyruvate carboxylase (see Fig. 12; for review, see Schousboe et al., 1997). Of these, only the process catalyzed by GDH directly produces NADH (see reaction 4 in Discussion). In contrast, pyruvate carboxylase hydro-

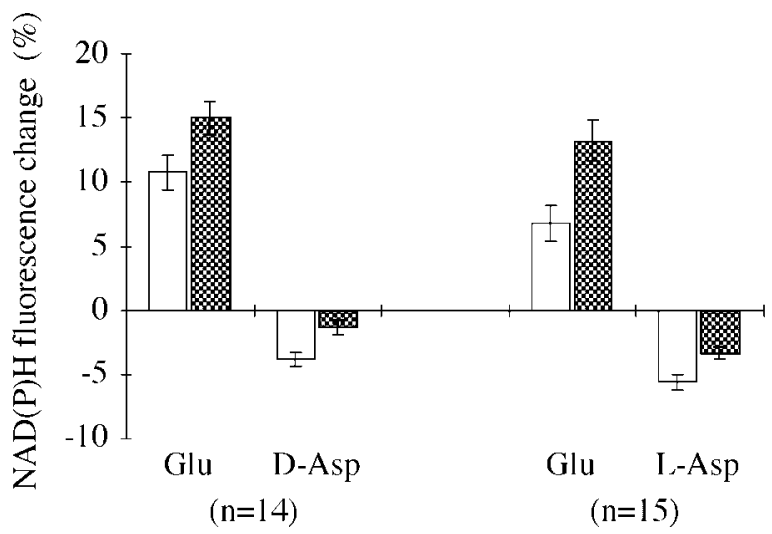

Figure 5. The glutamate-induced NAD(P)H response does not simply reflect the activity of the glutamate transporter. Comparison of the effects of glutamate $(200 \mu \mathrm{M})$ and either D- or L-aspartate $(200 \mu \mathrm{M})$, which both enter Müller cells by the same transporter as glutamate (Barbour et al., 1993), on NAD(P)H fluorescence in the distal processes of Müller cells. The histogram gives the amplitude of the NAD $(\mathrm{P}) \mathrm{H}$ response at the end (white columns; $\pm \mathrm{SE}$ ), and $30 \mathrm{sec}$ after the end (shaded columns; $\pm \mathrm{SE}$ ), of the $30 \mathrm{sec}$ period during which the test solution was pressure-ejected. The number of cells in which response pairs were recorded is given in parentheses.

lyzes ATP and may therefore indirectly cause a decrease in mitochondrial NADH by increasing mitochondrial respiration.

To probe the relative importance of transamination in the reactions occurring in an intact isolated Müller cell, we performed experiments using either a high concentration of pyruvate or the well known inhibitor of transaminases, aminooxyacetate (AOAA; Westergaard et al., 1996). Haslam and Krebs (1963) found that $10 \mathrm{~mm}$ of pyruvate strongly inhibited oxaloacetate transamination in brain homogenates, and Dennis and Clark (1978) observed the same in their nonsynaptic mitochondria. Our results in acutely isolated Müller cells show that, after 15 min of exposure to $10 \mathrm{~mm}$ pyruvate, a puff of glutamate did not induce more of an increase of $\mathrm{NAD}(\mathrm{P}) \mathrm{H}$ fluorescence (Fig. $6 A$ ). In contrast, exposure of a Müller cell for $1 \mathrm{hr}$ to a high concentration of AOAA (5 mM), had a negligible effect on the basal NAD $(\mathrm{P}) \mathrm{H}$ 
$A$

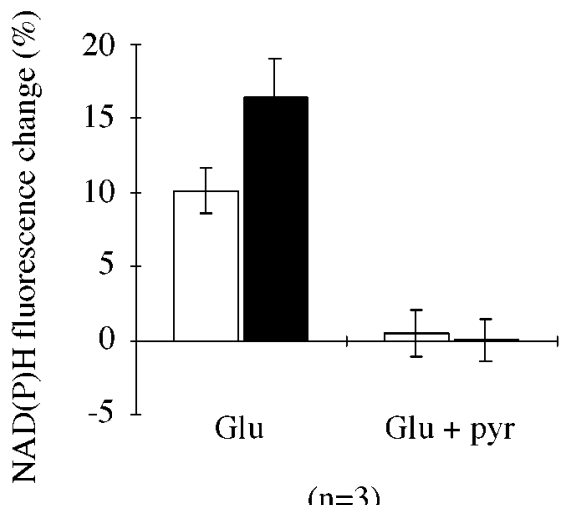

$B$

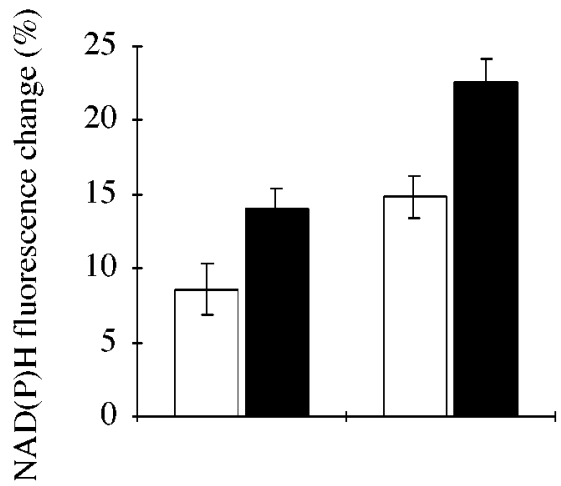

Glu

$\mathrm{Glu}+\mathrm{AOAA}$

$(n=3)$

Figure 6. Effects of a high concentration of pyruvate or of AOAA on the $\mathrm{NAD}(\mathrm{P}) \mathrm{H}$ response elicited by pressure ejection of $200 \mu \mathrm{M}$ glutamate. $A$, Histogram of the response amplitude at the end (white columns; $\pm \mathrm{SE}$ ), and $30 \mathrm{sec}$ after the end (shaded columns; $\pm \mathrm{SE}$ ), of the $30 \mathrm{sec}$ pressureejecting period in normal Ringer's solution (left) and after 15-40 min in $10 \mathrm{~mm}$ pyruvate-Ringer's solution (right). Response pairs were collected in three cells. $B$, Effect of exposing the cells to $5 \mathrm{~mm}$ AOAA. Histogram of the amplitude at the end (white columns; $\pm \mathrm{SE}$ ) and $30 \mathrm{sec}$ after the end (shaded columns; $\pm \mathrm{SE}$ ) of the $30 \mathrm{sec}$ pressure-ejecting period. Response pairs were collected in three cells, and the duration of exposure to AOAA ranged from 30 to $70 \mathrm{~min}$.

fluorescence and caused a slight increase in the glutamateinduced rise of NAD(P)H fluorescence (Fig. 6B). Our interpretation of these results is that GDH-catalyzed deamination of glutamate is the major TCA anaplerotic process in Müller cells maintained in simple Ringer's solution, as is also the case in cultured astrocytes (Westergaard et al., 1996). Thus, this process appears to be a major source of mitochondrial NADH. Probably, pyruvate at high concentration was metabolized through the pyruvate carboxylase reaction, leading to a massive increase of oxaloacetate and, as a consequence, to a massive increase of $\alpha$-ketoglutarate. This, in turn, inhibited both transamination and deamination of glutamate in the mitochondria (see Fig. 12, diagram and Discussion) and thereby suppressed the NAD $(\mathrm{P}) \mathrm{H}$ response. AOAA, on the other hand, probably blocked the transamination of glutamate and thereby favored its deamination, leading to an increased $\mathrm{NAD}(\mathrm{P}) \mathrm{H}$ response.

Because pyruvate is the end product of aerobic glycolysis, the results of Figure $6 A$ suggest a link between the rate of glycolysis and the mode of oxidation of transported glutamate. Therefore, we determined whether activation of glycolysis affected mitochondrial NADH. We tested the effect of $\mathrm{NH}_{4}{ }^{+}$, first because biochemical evidence shows that $\mathrm{NH}_{4}{ }^{+}$at $1 \mathrm{~mm}$ is an allosteric activator of phosphofructokinase (PFK), which is one of the enzymes controlling the glycolytic flux (Lowry and Passonneau, 1966), and second because stimulation of the isolated amphibian retina has been found to cause an increase in the concentration of ammonia released in the extracellular fluid (Kar and Arnold, 1992). In addition, deamination of glutamate by mitochondrial GDH would produce $\mathrm{NH}_{4}{ }^{+}$.

\section{Ammonia transport and signaling}

In the honeybee glial cells (Tsacopoulos et al., 1997a,b; Marcaggi et al., 1999), cultured mouse astrocytes (Brookes, 1997), and kidney cells (Kikeri et al., 1989), evidence based on measurements of intracellular $\mathrm{pH}$ indicates that $\mathrm{NH}_{4}{ }^{+}$ions, rather than $\mathrm{NH}_{3}$, enter these cells. Exposure of a Müller cell to 50-200 $\mu \mathrm{M}$ $\mathrm{NH}_{4} \mathrm{Cl}$ had small ( $\leq 0.1 \mathrm{pH}$ unit) and variable effects on intracellular $\mathrm{pH}$, but exerted a strong metabolic effect (see below). This suggests that ammonia could enter a Müller cell as $\mathrm{NH}_{3}$ and $\mathrm{NH}_{4}{ }^{+}$in a proportion that depends on the metabolic state of the cell, but in a sufficient amount to specifically affect cell metabolism.

We explored these metabolic effects of $\mathrm{NH}_{4}{ }^{+}$on acutely isolated Müller cells. For this, we made purified islands of acutely isolated Müller cells (Fig. 7A) and constructed enzyme-based lactate-sensitive microelectrodes (see Materials and Methods; Poitry et al., 1997) to measure net lactate release by these cells. The cells were bathed for 3-5 hr in a stagnant Ringer's solution carrying $0.5 \mathrm{~mm}$ glucose (physiological concentration in the mammalian brain; Lowry et al., 1998). The lactate concentration measured was virtually zero far from the cells, but when the lactate electrode was positioned near the cells of the island (Fig. $7 A$ ), the measured value was in the range of $2-8 \mu \mathrm{M}$ (Fig. $7 B$ ), depending on the size of the island. This result indicates a continuous production and release of lactate by Müller cells. In the presence of $100 \mu \mathrm{M}$ glutamate in the bathing solution, exposure of the cells to $100 \mu \mathrm{M} \mathrm{NH} \mathrm{NH}_{4} \mathrm{Cl}$ induced a large increase in lactate release (Fig. $7 C$ ). All islands tested $(n=10)$ showed this $\mathrm{NH}_{4}{ }^{+}$-induced lactate release (range, $10-50 \mu \mathrm{M}$ at the peak). In the absence of added glutamate, $\mathrm{NH}_{4}{ }^{+}$had no measurable effect (Fig. 7D). Calculations indicated that even if Müller cells had released their entire content of lactate under the combined effect of $\mathrm{NH}_{4}{ }^{+}$and glutamate, the concentration of lactate in the bathing solution near the cells would never reach such a high concentration without a concomitant strong stimulation of the production of lactate.

We checked that the signal of the lactate-sensitive microelectrode was not affected by the presence of $200 \mu \mathrm{M}$ glutamate, $\mathrm{NH}_{4} \mathrm{Cl}$, glutamine, and alanine (the two latter compounds are released by Müller cells, as shown below). However, there was still the possibility that the microelectrode sensed another compound directly oxidized on the Pt electrode. This was tested by using the same Pt electrode, but the lactate oxidase normally immobilized in the polymer was omitted. With such an electrode, polarized at $+600 \mathrm{mV}$, we recorded neither a gradient nor an effect of $\mathrm{NH}_{4}{ }^{+}$and glutamate on the measured current. These results suggest, first, that this enzyme-based electrode recorded specifically lactate; second, that acutely isolated Müller cells do not release measurable quantities of molecules oxidizable at this voltage (e.g., catecholamines, vitamins); and third, that $\mathrm{NH}_{4}{ }^{+}$in 
$\boldsymbol{A}$

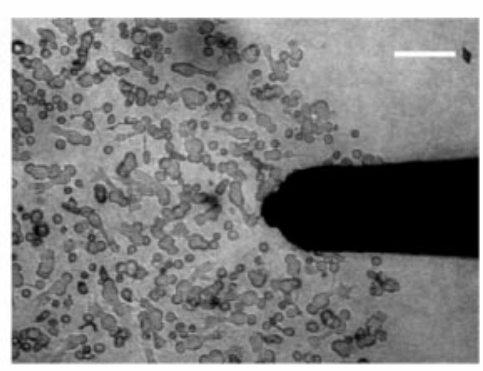

C

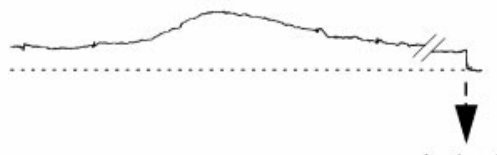

in bath

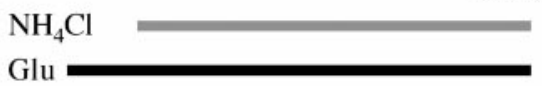

B

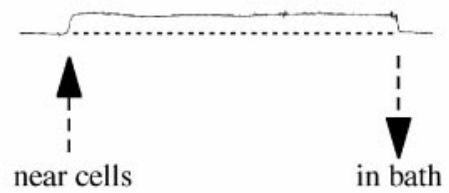

D

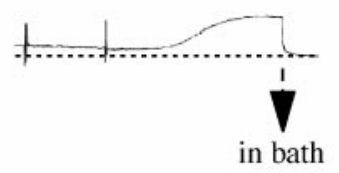

$\mathrm{NH}_{4} \mathrm{Cl}$

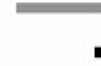

Glu

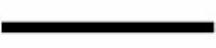

Figure 7. Cooperative effect of $\mathrm{NH}_{4}{ }^{+}$and glutamate on lactate production and release. $A$, Picture showing a portion of a microisland made of $\sim 250$ freshly isolated Müller cells. Also shown is a lactate microsensor with its tip positioned close to the cells. Scale bar, $100 \mu \mathrm{m}$. B, When the microsensor was approaching the cells from the bath, the lactate signal increased, indicating the existence of a lactate concentration gradient. $C$, Exposure of the cells to $100 \mu \mathrm{M}$ glutamate (solid bar) had no effect on the lactate signal, but addition of $100 \mu \mathrm{M} \mathrm{NH}_{4} \mathrm{Cl}$ (gray bar) in the presence of $100 \mu \mathrm{M}$ glutamate induced a large increase in lactate concentration. Withdrawal of the microprobe from the cells into the bath caused the lactate signal to decrease close to zero (zero level is indicated by the dotted line). The interruption in the trace corresponds to a $30 \mathrm{~min}$ period. $D$,

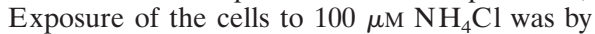
itself insufficient to induce a detectable increase of lactate concentration. Only after further addition of $100 \mu \mathrm{M}$ glutamate was a lactate response recorded. $E$, Lactate responses elicited by the cooperative action of glutamate and $\mathrm{NH}_{4} \mathrm{Cl}(100$ $\mu \mathrm{M}$ each) were transient, but could be repeated by further addition of glutamate and $\mathrm{NH}_{4} \mathrm{Cl}$ (bath concentration increased to $200 \mu \mathrm{M}$ for each, indicated by thickening of the solid bars). The measurement in $E$ was done on the island shown in $A$, which comprised three to four times more cells than those used in the other measurements.

the presence of glutamate, or vice versa, strongly increases the production and the release of lactate.

As shown in Figure $7 E$, the increased production of lactate was transient, in spite of the continuous presence of $\mathrm{NH}_{4}{ }^{+}$in the bathing solution, and it could be elicited again only after further addition of glutamate and $\mathrm{NH}_{4}{ }^{+}$. Bathing the cells in a Ringer's solution carrying a 10 times higher concentration of glucose did not prolong the duration of this lactate increase (result not shown), indicating that the reaction was not limited by glucose availability. Therefore, the result of Figure $7 E$ suggests that the increase in lactate production is linked to a reaction shared by the metabolism of both glutamate and $\mathrm{NH}_{4}{ }^{+}$, and that this reaction may have been limited in our experiments by the availability of either one of the reactants. Indeed, to allow detection of released lactate, the bath was left stagnant after the addition of glutamate and $\mathrm{NH}_{4}{ }^{+}$; thus, after the first addition of glutamate and $\mathrm{NH}_{4}{ }^{+}$, a high uptake rate of either glutamate or $\mathrm{NH}_{4}{ }^{+}$may have caused their concentration to decrease much below bath value, in the vicinity of the cells, so that the reaction became diff usion-limited. After further addition of glutamate and $\mathrm{NH}_{4}{ }^{+}$, the solution was mixed, and the concentration near the cells probably increased transiently to the bath value, allowing lactate production to in- crease transiently again. This interpretation is in agreement with the large decrease in $\left[\mathrm{NH}_{4}{ }^{+}\right]$measured with our ammonia sensor (see below and Fig. $8 \mathrm{~B}$ ). We show below that the reaction shared by glutamate and $\mathrm{NH}_{4}{ }^{+}$is the synthesis of glutamine.

\section{Glutamine synthesis and release}

The ammonia content of isolated glial cells decreases with time after isolation, in solution containing no added ammonia (Tsacopoulos et al., 1997a,b). In cultured cortical astrocytes, Waniewski (1992) showed that, at very low concentrations of ammonia in the bathing medium, the production and release of glutamine were increased when the cells were exposed to added $\mathrm{NH}_{4}{ }^{+}$, at a concentration as low as $50 \mu \mathrm{M}$. The enzyme that catalyzes the formation of glutamine from glutamate and $\mathrm{NH}_{4}{ }^{+}$at the expense of ATP is glutamine synthetase (GS). Using classical immunocytochemistry, we found that in the salamander retina GS activity is localized throughout the cytosol of Müller cells, consistent with previous findings in the mammalian retina and brain (Derouiche and Rauen, 1995; Derouiche et al., 1996). It is particularly interesting that this activity is preserved in acutely isolated cells maintained under the conditions described above (results not shown). Consequently, we expected that exposure of these cells to 

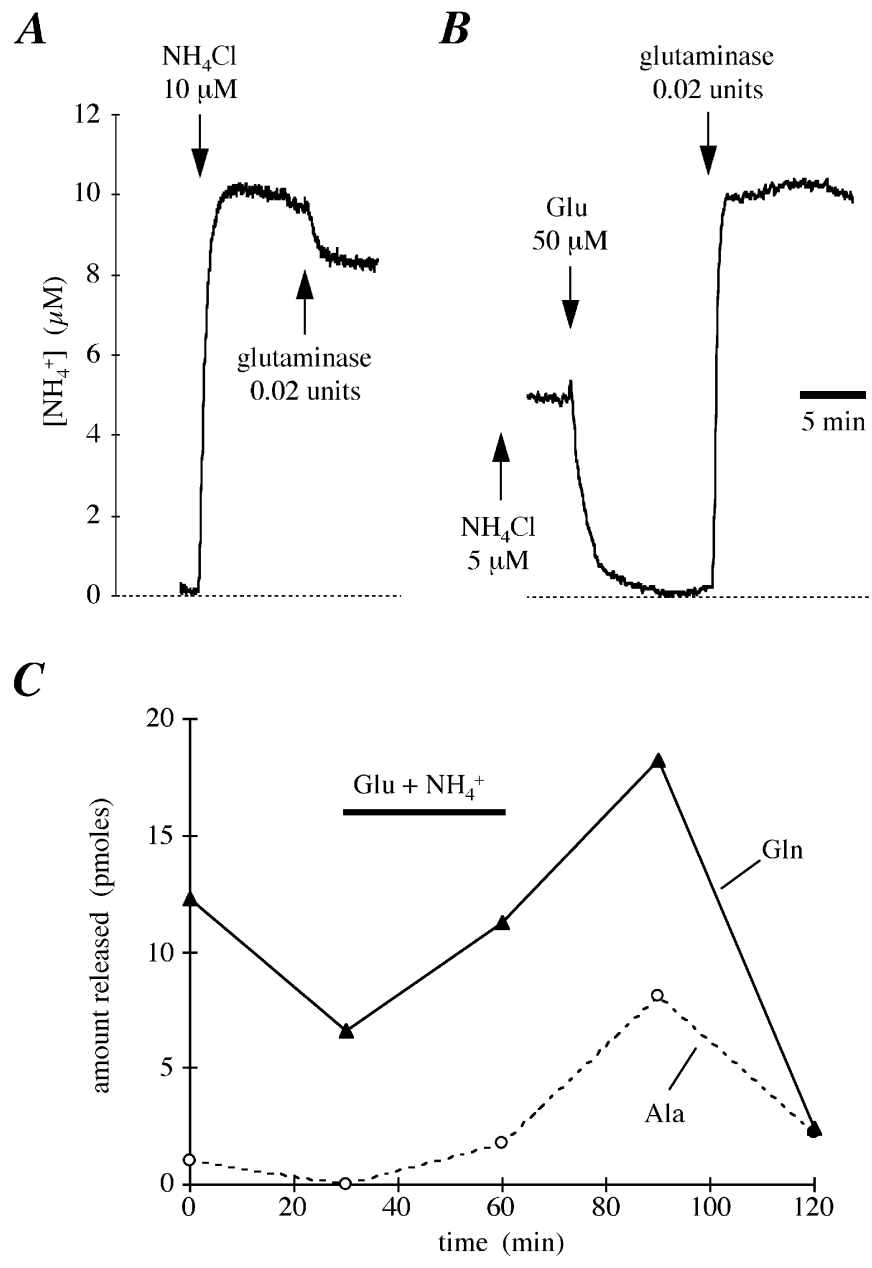

Figure 8. Glutamine is produced and released by Müller cells exposed simultaneously to glutamate and $\mathrm{NH}_{4} \mathrm{Cl} . A, B$, Measurements of $\left[\mathrm{NH}_{4}{ }^{+}\right]$ by a fiber-optic ammonia sensor. To optimize the detection of ammonia, the $\mathrm{pH}$ of the bathing solution in this type of experiment was adjusted to 7.8. $A$, Control experiment. When the sensor was in the bath, addition of neutral glutaminase (100 $\mu$ l, in Ringer's solution at $\mathrm{pH} 7.8$, added to $2 \mathrm{ml}$ bath; final activity: $0.01 \mathrm{U} / \mathrm{ml}$ ) did not produce an increase in the $\left[\mathrm{NH}_{4}{ }^{+}\right]$ signal, but a decrease caused by dilution, indicating that the glutaminase solution contained much less than $10 \mu \mathrm{M} \mathrm{NH}_{4}{ }^{+}$. $B$, When the sensor was positioned close to freshly isolated Müller cells forming a microisland (Fig. $7 A$ ), and after cells were exposed to glutamate and $\mathrm{NH}_{4}{ }^{+}$, addition of glutaminase caused a large increase in $\left[\mathrm{NH}_{4}{ }^{+}\right]$. Twenty minutes before the beginning of this record, $5 \mu \mathrm{M} \mathrm{NH_{4 }} \mathrm{Cl}$ was added to the Ringer's solution bathing the cells. As shown, further addition of $50 \mu \mathrm{M}$ glutamate caused a rapid drop of $\left[\mathrm{NH}_{4}{ }^{+}\right]$near the cells, indicating substantial uptake of ammonia by the cells. The time constant of this drop was similar to the time constant of the sensor response. After $10 \mathrm{~min}$ of exposing the cells to glutamate and $\mathrm{NH}_{4}{ }^{+}$, glutaminase was added to the bath, causing the rapid hydrolysis of glutamine present in the bath and a concomitant increase of $\left[\mathrm{NH}_{4}^{+}\right]$. C, Amounts of glutamine (Gln, filled triangles) and alanine (Ala, open circles) released into the bath by a microisland of $\sim 850$ Müller cells after 30 min incubating periods in normal Ringer's solution (all bath collections except third) or in Ringer's solution containing glutamate and $\mathrm{NH}_{4} \mathrm{Cl}(50 \mu \mathrm{M}$ each, third bath collection). Exposure to glutamate and $\mathrm{NH}_{4} \mathrm{Cl}$ caused a sizable increase in the production and release of glutamine and alanine. Amino acid content of bath collections was measured by HPLC, using ortho-phthalaldehyde derivatization.

micromolar concentrations of $\mathrm{NH}_{4}{ }^{+}$would elicit an increase of glutamine synthesis and release.

We tested this expectation by monitoring the release of glutamine by Müller cells, using a technique that combines a fiber-
$\boldsymbol{A}$

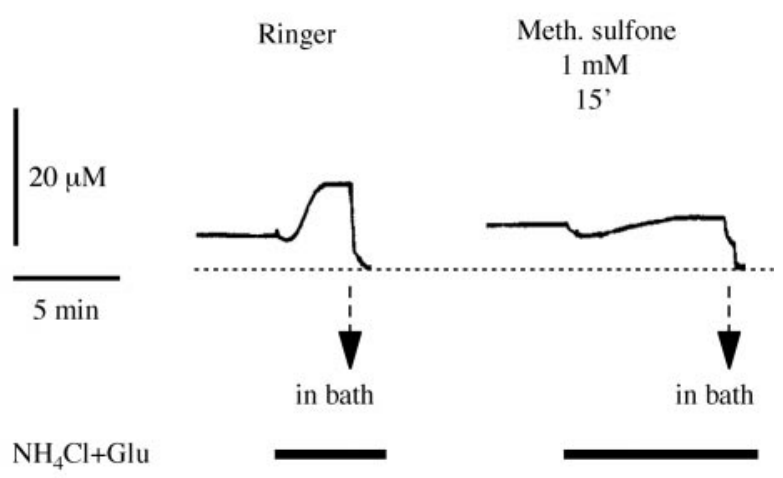

B

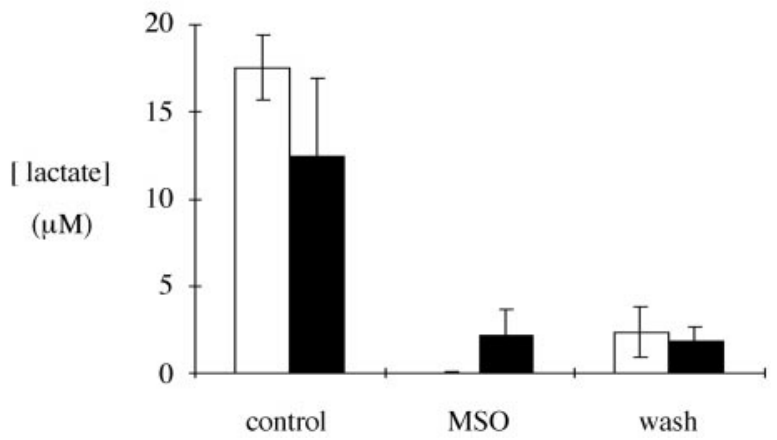

Figure 9. The lactate response is linked to the activity of glutamine synthetase. $A$, Lactate measurements showing that exposure of Müller cells to $1 \mathrm{~mm}$ methionine sulfone inhibits the increase in lactate production induced by glutamate $+\mathrm{NH}_{4}{ }^{+}(100 \mu \mathrm{M}$ each). $B$, Histogram showing the effects of $3 \mathrm{~mm}$ methionine sulfoximine (white columns; 2 cells) and 3 $\mathrm{mm}$ methionine sulfone (black columns; 6 cells) on the lactate response induced by glutamate $+\mathrm{NH}_{4}{ }^{+}$. Suppression of the response during exposure to the inhibitor (central column, MSO) was not reversed $1 \mathrm{hr}$ after returning the preparation to normal Ringer's (right columns, wash).

optic ammonia sensor with the extracellular application of partially purified glutaminase diluted in the bathing solution, at $\mathrm{pH}$ 7.8. At this $\mathrm{pH}$, the "neutral" enzyme we used has its maximum activity, and $\sim 4 \%$ of the ammonia produced is in gaseous form and thus sensed by the probe. Under these conditions, and because the added glutaminase solution had the same $\mathrm{pH}$ as the bathing solution and did not contain ammonia (Fig. 8A), any increase in ammonia detected after addition of glutaminase should result only from the hydrolysis of glutamine by glutaminase. To detect glutamine produced by the cells, a purified Müller cell island was bathed with Ringer's solution containing $5 \mu \mathrm{M}$ $\mathrm{NH}_{4}{ }^{+}$. The ammonia sensor was advanced in the bath, and its tip was positioned close to the cells. No gradient of $\mathrm{NH}_{4}{ }^{+}$concentration was detected. The addition of $50 \mu \mathrm{M}$ glutamate induced then a rapid decrease of $\mathrm{NH}_{4}{ }^{+}$in the bath near the cells (Fig. $8 B$ ). We suggest that added glutamate was transported into the Müller cells where it induced an increase of glutamine synthesis. This is likely because the $K_{\mathrm{m}}$ of brain GS for glutamate is much higher than for $\mathrm{NH}_{4}{ }^{+}$(see Pamiljans et al., 1962; for human brain, Listrom et al., 1997). Probably, in our experiments, the glutamate-induced increase of glutamine synthesis used intracellular $\mathrm{NH}_{4}{ }^{+}$, thus increasing the transmembrane gradient of $\mathrm{NH}_{4}{ }^{+}$concentration. This, in turn, facilitated the entry of $\mathrm{NH}_{4}{ }^{+}$ from the extracellular space and caused the observed decrease of $\left[\mathrm{NH}_{4}{ }^{+}\right]$near the cells. Demonstration that the glutamateinduced decrease of extracellular $\left[\mathrm{NH}_{4}{ }^{+}\right]$might be attributable 

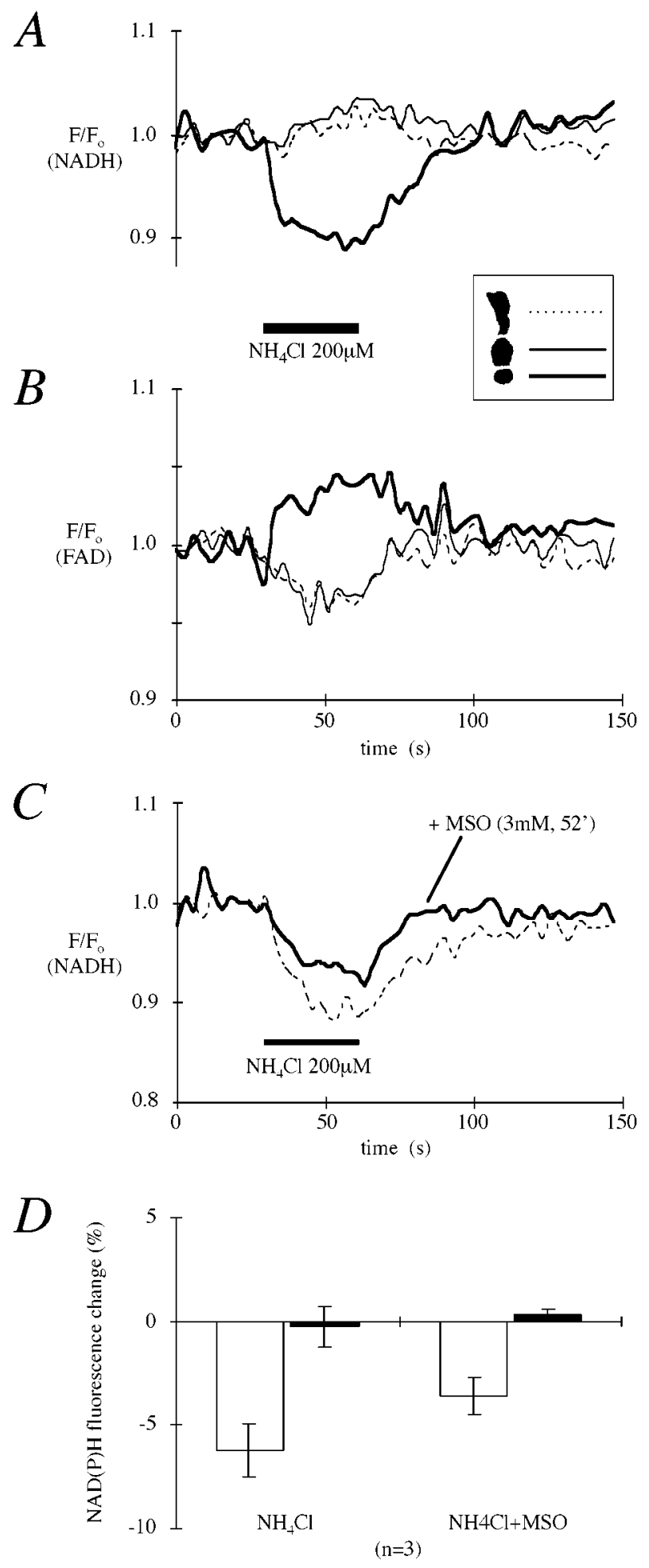

Figure 10. Changes in the mitochondrial redox potential of Müller cells are linked to the activity of glutamine synthetase. $A, B$, Exposure of a Müller cell to $200 \mu \mathrm{M} \mathrm{NH} \mathrm{N}_{4} \mathrm{Cl}$ caused a decrease of NAD(P)H fluorescence and an increase of FAD fluorescence in the distal processes (thick solid traces, see inset) where mitochondria are packed, but not in other regions of the cell. $C$, The $\mathrm{NAD}(\mathrm{P}) \mathrm{H}$ response elicited by $\mathrm{NH}_{4}{ }^{+}$in the distal processes is decreased by $3 \mathrm{~mm}$ MSO, an inhibitor of glutamine synthetase. The response in MSO-Ringer's (dashed line) was recorded 50 min after switching solution. $D$, Effect of $\mathrm{MSO}$ on the $\mathrm{NAD}(\mathrm{P}) \mathrm{H}$ response induced by $200 \mu \mathrm{M} \mathrm{NH} \mathrm{N}_{4} \mathrm{Cl}$. Histogram of the amplitude at the end (white columns; $\pm \mathrm{SE}$ ), and $30 \mathrm{sec}$ after the end (shaded columns; $\pm \mathrm{SE}$ ), of the 30 to an increased rate of glutamine synthesis was provided by showing that the cells had produced and released an equivalent amount of glutamine. Indeed, as shown in Figure $8 B$, addition of $0.02 \mathrm{U}$ of glutaminase to the bathing solution caused a sharp increase of the concentration of ammonia, because glutaminase rapidly transformed the glutamine released by the cells to glutamate and $\mathrm{NH}_{4}{ }^{+}$. Similar results were obtained in five Müller cell islands with five different sensors. The concentration of ammonia after glutaminase addition was higher than before the addition of glutamate probably because some glutamine synthesis and release occurred before the exposure to glutamate.

These results are confirmed by HPLC analysis of the bathing solution showing that, before the exposure of Müller cells to 200 $\mu \mathrm{M} \mathrm{NH}_{4}{ }^{+}$and glutamate and the consecutive increase in glutamine production, there was a measurable, but slowly decreasing, release of glutamine into the bath (Fig. 8C). We conclude that acutely isolated Müller cells produce and release glutamine and that this production in the presence of micromolar concentration of ammonia is strongly stimulated by glutamate.

\section{Link between glutamine synthesis and glycolysis}

Because exposure to $\mathrm{NH}_{4}{ }^{+}$and glutamate caused a massive increase in lactate production (Fig. 7), the natural question then was whether this effect was a direct consequence of the increased rate of glutamine synthesis. This possibility was tested by measuring lactate concentration near Müller cell islands in the presence of 1 or $3 \mathrm{~mm}$ methionine sulfoximine (MSO), a well established specific inhibitor of GS (Meister, 1974). Whereas the basal level of lactate production and release by Müller cells did not change significantly after addition of MSO, the increase in lactate production elicited by $\mathrm{NH}_{4}{ }^{+}$and glutamate was irreversibly suppressed within $30 \mathrm{~min}$ (Fig. 9B). The irreversibility of this effect was expected, because MSO has been shown to undergo phosphorylation after binding to the glutamate site of GS, thereby permanently inactivating the enzyme (Meister, 1974). However, 1 or $3 \mathrm{~mm}$ of methionine sulfone, whose inhibitory action on GS was reported to be more reversible than MSO (Rowe et al., 1969), produced the same effects (Fig. 9A), irreversible within $1 \mathrm{hr}$ after application (Fig. 9B), which suggests that these inhibitors tend to accumulate in the cells.

The effects of MSO and methionine sulfone were consistent with the idea that the increase in lactate production elicited by $\mathrm{NH}_{4}{ }^{+}+$glutamate was a consequence of the increased rate of glutamine synthesis. Moreover, because the inhibition of GS should produce an elevation of the intracellular level of $\mathrm{NH}_{4}{ }^{+}$, these effects excluded a direct role of $\mathrm{NH}_{4}{ }^{+}$in the activation of glycolysis and lactate production. A possible link between glycolysis and glutamine synthesis is ATP (or its hydrolysis products ADP and $\mathrm{P}_{\mathrm{i}}$ ), because the GS reaction consumes ATP and because the activity of PFK is known to be regulated by the levels of ADP and $\mathrm{P}_{\mathrm{i}}$ (Lowry and Passonneau, 1966). As mentioned above, GS is also present in the distal processes of the Müller cell and, therefore, changes in the cytosolic levels of ADP and $\mathrm{P}_{\mathrm{i}}$ caused by increased glutamine synthesis may also lead to increased mitochondrial respiration. We explored this possibility by measuring NAD $(\mathrm{P}) \mathrm{H}$ fluorescence during exposure of the Müller

$\leftarrow$

sec pressure-ejecting period in normal Ringer's (left) and after 10-60 min of exposure to $3 \mathrm{~mm}$ MSO-Ringer's (right). Response pairs were collected in three cells. Response amplitudes at the end of the pressure-ejecting period were significantly lower in MSO ( $p<0.01$; paired $t$ test). 


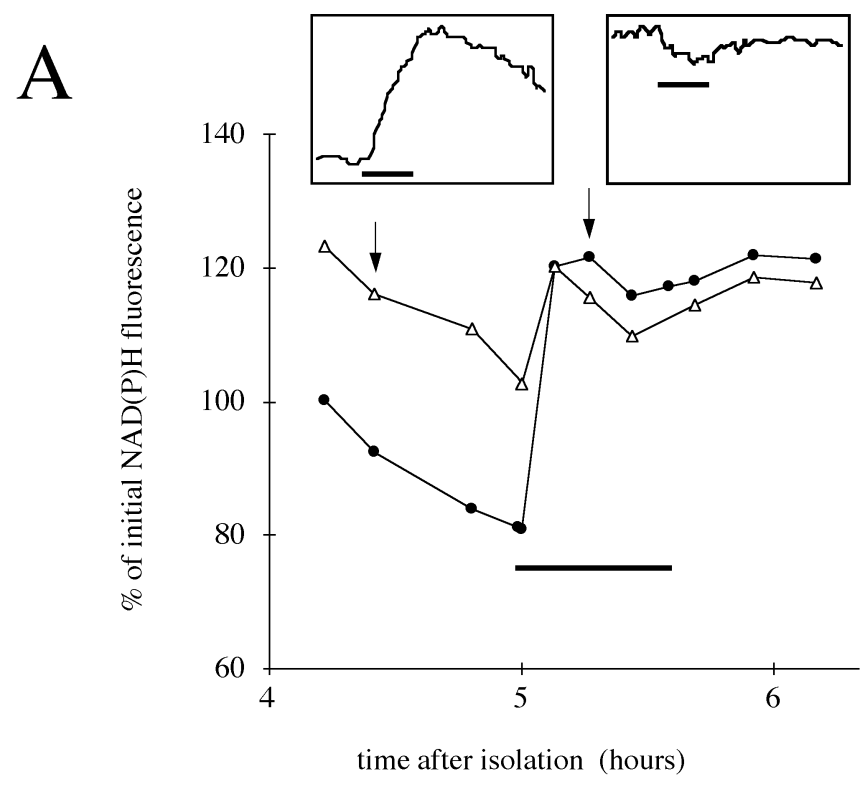

B

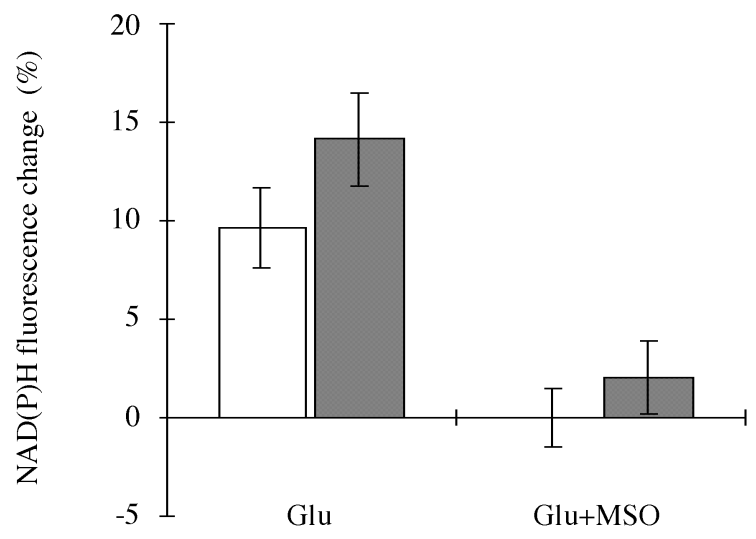

$(n=12)$

Figure 11. The glutamate-induced NAD $(\mathrm{P}) \mathrm{H}$ response is linked to the activity of glutamine synthetase. $A$, Plot of the basal level of NAD $(\mathrm{P}) \mathrm{H}$ fluorescence (filled circles) and of the fluorescence at the peak of glutamate-induced responses (open triangles) as a function of time after cell isolation, and effects of exposure to $3 \mathrm{~mm}$ MSO (solid bar). The basal fluorescence decreased slightly with time after cell isolation, but MSO caused it to increase back toward a maximal value and suppressed the glutamate-induced increase of fluorescence. Arrows indicate the times at which the glutamate-induced $\mathrm{NAD}(\mathrm{P}) \mathrm{H}$ responses shown in insets were recorded. Insets, Time course of the glutamate-induced NAD(P)H responses recorded at the times indicated by arrows on the plot. Glutamate $(200 \mu \mathrm{M})$ was pressure-ejected during $30 \mathrm{sec}$, as indicated by the solid bar under the traces. $B$, Effect of exposing the cells to $3 \mathrm{~mm} \mathrm{MSO}$ on the glutamate-induced $\mathrm{NAD}(\mathrm{P}) \mathrm{H}$ response. Histogram of the amplitude at the end (white columns; $\pm \mathrm{SE}$ ), and $30 \mathrm{sec}$ after the end (shaded columns; $\pm \mathrm{SE}$ ), of the $30 \mathrm{sec}$ pressure-ejecting period. The number of cells in which response pairs were recorded is given in parentheses.

cell to $\mathrm{NH}_{4}{ }^{+}$. As shown in Figure $10 A$, puffing $200 \mu \mathrm{M} \mathrm{NH} \mathrm{N}_{4} \mathrm{Cl}$ for $30 \mathrm{sec}$ induced a large monophasic and transient decrease of $\mathrm{NAD}(\mathrm{P}) \mathrm{H}$, a change occurring only in the distal processes of the cell. The same puff caused a parallel, but smaller, increase in flavin adenine dinucleotide (FAD) fluorescence (Fig. 10B). FAD is the hydrogen acceptor of the reaction converting succinate to fumarate in the TCA cycle and is produced by the respiratory chain (Fig. $3 B$ ). Thus, probably ADP and $\mathrm{P}_{\mathrm{i}}$ produced by the increased flux through the GS reaction stimulated mitochondrial respiration. As shown in Figure 10, $C$ and $D$, exposure to MSO decreased significantly, but did not abolish the effect of $\mathrm{NH}_{4}{ }^{+}$on $\mathrm{NAD}(\mathrm{P}) \mathrm{H}$ fluorescence. This incomplete effect of MSO, even after a rather long incubation period, indicates that $\mathrm{NH}_{4}{ }^{+}$probably decreases NAD(P)H fluorescence also via another reaction than that catalyzed by GS, for example by decreasing the flux of glutamate through the glutamate dehydrogenase reaction (see Fig. 12).

Then we asked whether inhibition of glutamine synthetase by MSO has as a major consequence an increase in intraglial glutamate availability to other metabolic pathways. As shown in Figure $11 A$, we measured the mitochondrial NAD(P)H fluorescence as a function of time after exposure of Müller cells to normal (glutamate-free) Ringer's solution. The basal NAD(P)H fluorescence decreased steadily with time, possibly because of a sustained loss of TCA intermediates, but puffs of glutamate induced large rises of $\mathrm{NAD}(\mathrm{P}) \mathrm{H}$ (Fig. 11A). Then, the cell was exposed to $3 \mathrm{~mm} \mathrm{MSO}$, which caused a rapid $40 \%$ rise of the basal $\mathrm{NAD}(\mathrm{P}) \mathrm{H}$ fluorescence in the distal processes and suppressed the glutamate-induced rise of NAD(P)H fluorescence (Fig. 11 $A, B$ ). Our interpretation is that, in the presence of MSO, glutamate is available to enter the TCA cycle, thus leading to a nearly maximum turnover rate of the cycle and consequently to the accumulation of NADH. Under this condition, the transported glutamate could not increase further mitochondrial NAD $(\mathrm{P}) \mathrm{H}$.

\section{DISCUSSION}

Based on the average current generated by the glutamate uptake, Barbour et al. (1993) calculated that the intracellular concentration of glutamate in Müller cells may rise at a rate of $\sim 0.5$ $\mathrm{mm} / \mathrm{sec}$. Therefore, exposing these cells for $30 \mathrm{sec}$ to $200 \mu \mathrm{M}$ glutamate may cause the intracellular concentration to increase up to $\sim 15 \mathrm{~mm}$, if no transformation of glutamate occurred. However, the similarity of the time courses of $\triangle \mathrm{NAD}(\mathrm{P}) \mathrm{H}$ and $\Delta \mathrm{pH}_{\mathrm{i}}$, both measured by optical techniques in this study (Fig. $2 B$ ), clearly demonstrates that transported glutamate activates metabolic reactions within seconds.

Our observations are consistent with the occurrence in a Müller cell of four biochemical reactions involving glutamate: (1) glutamate $+\mathrm{NH}_{4}{ }^{+}+\mathrm{ATP} \rightarrow$ glutamine $+\mathrm{ADP}+\mathrm{P}_{\mathrm{i}}$; (2) glutamate + pyruvate $\rightarrow$ alanine $+\alpha$-ketoglutarate; (3) glutamate + oxaloacetate $\Leftrightarrow \alpha$-ketoglutarate + aspartate; (4) glutamate + $\mathrm{NAD}^{+} \rightarrow \alpha$-ketoglutarate $+\mathrm{NADH}+\mathrm{NH}_{3}$. These reactions, already well established by previous biochemical work on brain homogenates, isolated brain mitochondria, and cultured astrocytes (for review, see Sonnewald et al., 1997), occur in the cytosol (reactions 1, 2, and 3), or in the mitochondria (reactions 3 and 4). Although they are all related in some way to the NADH redox potential, only reaction 4 is directly linked to it.

The interest of our work resides in the use of subcellular imaging of $\mathrm{NAD}(\mathrm{P}) \mathrm{H}$ fluorescence in an acutely isolated type of astrocyte in which there is a clear metabolic compartmentation. Measurements in the cytosol and in the mitochondria were thus possible, allowing us to probe simultaneously both cellular compartments and to explore the relationships between the abovementioned reactions and the complex signaling role of glutamate. We found that significant and rapid glutamate-induced $\mathrm{NAD}(\mathrm{P}) \mathrm{H}$ changes occurred only in the distal processes of the Müller cell, where most mitochondria are located. The rapid response is explained by the finding that the mitochondria are 


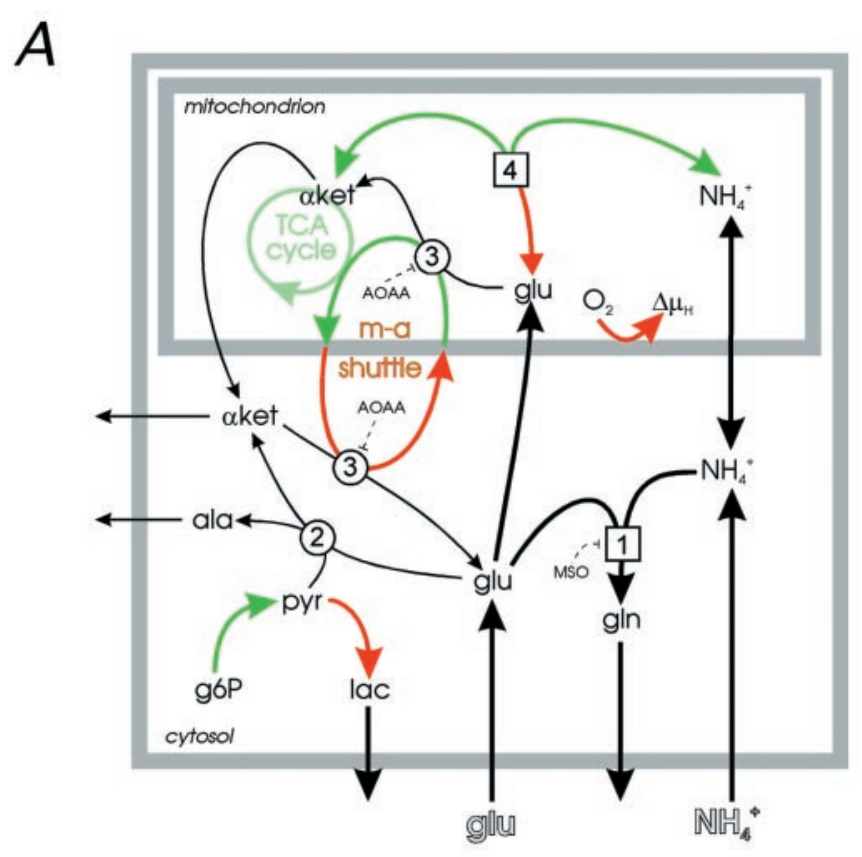

$B$

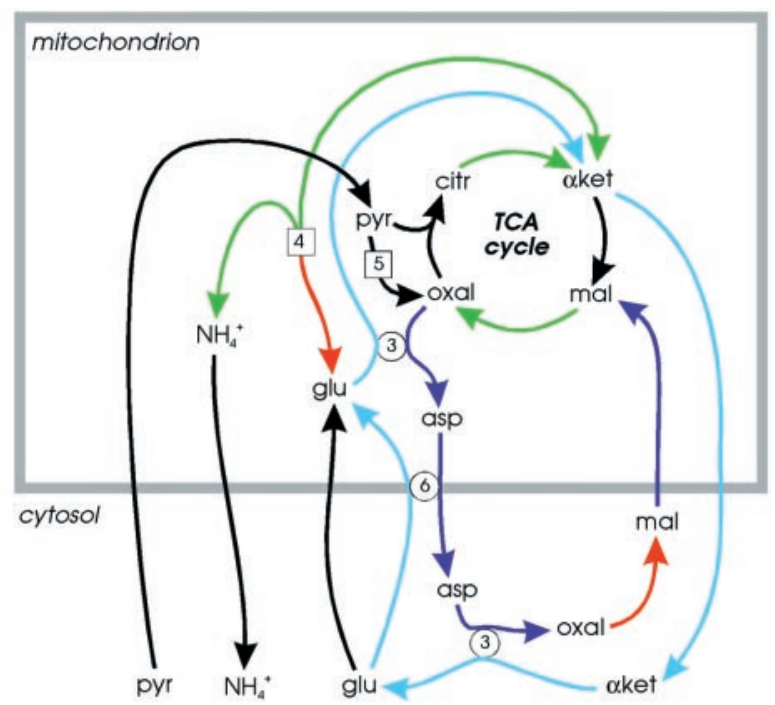

Figure 12. Model diagrams showing biochemical pathways involved in the trafficking and metabolism of glutamate $(g l u)$ and $\mathrm{NH}_{4}{ }^{+}(A)$ and metabolite exchanges between cytosol and mitochondrion $(B)$. Numbers indicate the reactions catalyzed by glutamine synthetase (1), alanine aminotransferase (2), aspartate aminotransferase (3), glutamate dehydrogenase (4), and pyruvate carboxylase (5), or the mitochondrial glutamate-aspartate exchange carrier (6); the circle indicates transaminating reactions and exchange carrier, and the square, other reactions. Also indicated are some inhibitors: MSO for reaction 1 and AOAA for reaction 3. Even though most of these reactions are reversible in principle, only the directions of the reactions considered in the analysis of our results are indicated. Colored arrows indicate whether NADH is produced (green) or consumed (red) in the reaction. Mitochondrial respiration is represented schematically as a single reaction consuming NADH and transforming oxygen $\left(\mathrm{O}_{2}\right)$ into a proton gradient $\left(\Delta \mu_{H}\right)$. The final product of the metabolism of glucose-6-phosphate $(\mathrm{g} 6 \mathrm{P})$, pyruvate $(\mathrm{pyr})$, is reduced to lactate (lac) by the enzyme lactate dehydrogenase. This reaction is essential for the production of $\mathrm{NAD}^{+}$, subsequently used by glycolysis. However, close to the mitochondrial surface the malate-aspartate shuttle (m-a shuttle; the reactions involved in this shuttle are indicated in light and dark blue in $B$ ) may contribute to the production of cytosolic NAD ${ }^{+}$. Glutamate $(\mathrm{glu})$ and $\mathrm{NH}_{4}{ }^{+}$are transported into the glial cell where they are located in a region of the cell where glutamate transport is intense (Tsacopoulos et al., 1998), so that intracellular glutamate concentration can increase rapidly. The observation that glutamate did not induce measurable changes of $\mathrm{NAD}(\mathrm{P}) \mathrm{H}$ in the soma, where glutamate transport is also intense, is compatible with the idea that metabolism there, as well as in the endfoot region, is predominantly glycolytic and that glutamate alone does not cause a rapid activation of glycolysis (see below and Hertz et al., 1998).

The shape of the glutamate-induced change of $\mathrm{NAD}(\mathrm{P}) \mathrm{H}$ depended strongly on whether the cell was tested shortly after isolation or a few hours later. With regard to this observation, we excluded a damage of the transport carrier because L- and D-aspartate elicited transport currents and NAD(P)H fluorescence decreases in all Müller cells, independently of time after isolation. We therefore believe that the parameter that changed over time after isolation was principally the metabolic state of the cells that was determined by the intracellular levels of glutamate and $\mathrm{NH}_{4}{ }^{+}$.

Our data show that reaction 1 catalyzed by GS (Fig. 12), which was found in the cytosol of isolated salamander Müller cells, was the major route for fixation of $\mathrm{NH}_{4}{ }^{+}$and hence for the transformation of cytosolic glutamate to glutamine. The demonstration, made by Cooper et al. (1979) in the intact rat brain, of glutamine synthesis $1-2$ sec after a bolus injection of ${ }^{13} \mathrm{~N}$-labeled ammonia into the blood stream, is consistent with our data. The high affinity of GS for ammonia and the lower affinity for glutamate, implies that at low, physiological concentrations of both reactants, ammonia is trapped by GS, and the production of glutamine is finely controlled by glutamate (Waniewski, 1992). Consequently, when the supply of ammonia is limited, as it was for our isolated Müller cells, production of glutamine continues until almost all available ammonia in the cells is trapped. When the flux through the GS reaction is limited by lack of sufficient amounts of ammonia (below $10 \mu \mathrm{M}$ ), then more glutamate is available to enter reactions 3 and 4 occurring in mitochondria. This is consistent with what occurs in MSO-treated rats (Cooper et al., 1979) and when cultured astrocytes are exposed to MSO (McKenna et al., 1996; Westergaard et al., 1996).

The metabolic fixation of ammonia utilizes ATP (reaction 1). Because the $K_{\mathrm{m}}$ of GS for ATP is high (2.5 mm; Meister, 1974), the cell must restore rapidly the ATP level to maintain glutamine synthesis. In Müller cells of all species examined so far, GS is found to be cytosolic, and the elegant study of Derouiche and Rauen (1995) demonstrated a colocalization of GS and of the glutamate transporter in the fine lateral processes of Müller cells. The uneven distribution of mitochondria, restricted to the distal processes of salamander Müller cells, suggests that a major part of the ATP used by GS is produced through the glycolytic pathway. Indeed, in the absence of mitochondrial contribution, lactate synthesis from pyruvate is necessary to maintain the redox potential of glycolysis, and exposure of Müller cells to micromolar concentrations of $\mathrm{NH}_{4}{ }^{+}$and glutamate stimulated the production and release of both lactate and glutamine. Moreover, the finding that the specific inhibitor of GS MSO suppressed the lactate increase induced by glutamate and $\mathrm{NH}_{4}{ }^{+}$strongly suggests that glutamine synthesis and glycolysis are coupled, proba-

$\leftarrow$

transformed to glutamine ( $g l n)$, alanine (ala), and $\alpha$-ketoglutarate $(\alpha k e t)$. These products leave the glial cell and are taken up by neurons. In this way nitrogen homeostasis can be maintained. asp, Aspartate; citr, citrate; mal, malate; oxal, oxaloacetate. 
bly via the cytosolic phosphate potential (ATP/ADP $+\mathrm{P}_{\mathrm{i}}$ ). A similar scheme was adopted by Sibson et al. (1998) in interpreting their brain ${ }^{13} \mathrm{C}$-NMR spectroscopy results obtained in anesthetized rats. We postulate that GS, like other ATP-requiring enzymes, is bound close to glycolytic enzymes, constituting an enzymatic complex. Hence, $\mathrm{P}_{\mathrm{i}}$ and ADP leaving the enzyme could stimulate glycolysis via allosteric activation of PFK (Lowry and Passonneau, 1966), and this activation of glycolysis might be efficient in restoring rapidly the level of ATP, in the vicinity of GS. Thus, under physiological conditions, the flux through the GS reaction might not be limited by the level of ATP, but by the intracellular concentration of ammonia. This hypothesis is consistent with findings obtained on rat brain by ${ }^{1} \mathrm{H}-{ }^{15} \mathrm{~N}-\mathrm{NMR}$, showing that GS activity is kinetically limited by suboptimal in situ concentration of ammonia (Kanamori et al., 1995).

The activation of glycolysis via increased glutamine production must lead to increased production of pyruvate. Despite the predominant reduction of pyruvate to lactate, some small amount might be transaminated by glutamate to alanine. The similar time course of the rises in glutamine and alanine elicited by glutamate and $\mathrm{NH}_{4}{ }^{+}$(Fig. $8 \mathrm{~B}$ ) supports this idea. Mammalian Müller cells and brain-cultured astrocytes produce alanine (Yudkoff et al., 1986; Poitry-Yamate et al., 1995). However, in contrast to honeybee retinal glial cells (Tsacopoulos et al., 1994), they do not possess a cytosolic glutamate dehydrogenase and, therefore, cannot reduce cytosolic $\alpha$-ketoglutarate back to glutamate to maintain the redox potential of glycolysis. In the perimitochondrial cytosol however, the aspartate-malate shuttle may contribute to regenerating cytoplasmic $\mathrm{NAD}^{+}$, by carrying malate, in lieu of NADH, across the mitochondrial membrane (Fig. 12). Thus, a link probably exists between the redox potential of glycolysis and the redox potential generated by the aspartate-malate shuttle. However, the results of Figure $6 \mathrm{~A}$ indicate that normally little pyruvate is available to enter the TCA cycle through the pyruvate carboxylase reaction and consequently the major anaplerotic process that fuels the TCA cycle with intermediates is the reaction catalyzed by glutamate dehydrogenase (reaction 4 ). This reaction yields the major part of the glutamate-induced increase of $\mathrm{NAD}(\mathrm{P}) \mathrm{H}$ fluorescence that we measured in this study. The quantity of glutamate that enters the TCA cycle was determined, in turn, by the flux through the GS reaction and the requirement of intramitochondrial transamination of oxaloacetate to aspartate. When more transported glutamate was available to enter the TCA cycle, the turnover of the cycle increased via the mitochondrial glutamate dehydrogenase reaction (for review, see Cooper and Plum, 1987), leading to a large rise of NAD(P)H fluorescence. This rise of $\mathrm{NAD}(\mathrm{P}) \mathrm{H}$ indicates that the increased turnover of the TCA cycle induced by glutamate transiently exceeded the flux of NADH through the respiratory chain (Fig. $3 B$ ). The results of Barbour et al. (1993) showing a glutamate-induced rise of NAD(P)H fluorescence in Müller cells dialyzed with patchclamp pipettes filled with $20 \mathrm{~mm}$ 2-deoxyglucose to abolish glycolysis and $0.1 \mathrm{~mm}$ malonate to inhibit succinate dehydrogenase, provide strong support to this hypothesis.

We conclude that ammonia fixation by GS controls the amount of lactate, glutamine, and alanine (and possibly also $\alpha$-ketoglutarate; Poitry-Yamate, 1994; Poitry-Yamate et al., 1995) produced and released by Müller cells in the extracellular space. Recent data show that solitary salamander rods, which in the intact retina are in close contact to Müller cells, take up lactate and alanine (in the presence of $\alpha$-ketoglutarate), but not glucose, and use them to fuel the TCA cycle in the mitochondria packed in the ellipsoid region of the rod (Kapetanios et al., 1998). The fate of glutamine is not known. Although it has not yet been established whether these nutrients contribute to the replenishment of neurotransmitter glutamate in photoreceptor-neurons (Yudkoff, 1997), our results strongly support the hypothesis that glutamate signals to Müller cells the metabolic requirements of neurons.

\section{REFERENCES}

Barbour B, Magnus C, Szatkowski M, Gray PT, Attwell D (1993) Changes in $\mathrm{NAD}(\mathrm{P}) \mathrm{H}$ fluorescence and membrane current produced by glutamate uptake into salamander Muller cells. J Physiol (Lond) 466:573-597.

Bouvier M, Szatkowski M, Amato A, Attwell D (1992) The glial cell glutamate uptake carrier countertransports $\mathrm{pH}$-changing anions. Nature 360:471-474.

Brew H, Attwell D (1987) Electrogenic glutamate uptake is a major current carrier in the membrane of axolotl retinal glial cells. Nature 327:707-709.

Bröer S, Rahman B, Pellegri G, Pellerin L, Martin JL, Verleysdonk S, Hamprecht B, Magistretti PJ (1997) Comparison of lactate transport in astroglial cells and monocarboxylate transporter 1 (MCT 1) expressing Xenopus laevis oocytes. Expression of two different monocarboxylate transporters in astroglial cells and neurons. J Biol Chem 272:30096-30102.

Brookes N (1997) Intracellular $\mathrm{pH}$ as a regulatory signal in astrocyte metabolism. Glia 21:64-73.

Chance B, Hess B (1959) Metabolic control mechanisms. I. Electron transfer in the mammalian cell. J Biol Chem 234:2404-2412.

Clark LC, Noyes LK, Grooms TA, Moore MS (1984) Rapid micromeasurement of lactate in whole blood. Crit Care Med 12:461-464.

Cooper AJ, Plum F (1987) Biochemistry and physiology of brain ammonia. Physiol Rev 67:440-519.

Cooper AJ, McDonald JM, Gelbard AS, Gledhill RF, Duffy TE (1979) The metabolic fate of $13 \mathrm{~N}$-labeled ammonia in rat brain. J Biol Chem 254:4982-4992.

Cosnier S, Innocent C, Allien L, Poitry S, Tsacopoulos M (1997) An easy electrochemical method for making enzyme microsensors. Application to the detection of dopamine and glutamate. Anal Chem 69:968-971.

Dennis SC, Clark JB (1977) The pathway of glutamate metabolism in rat brain mitochondria. Biochem J 168:521-527.

Dennis SC, Clark JB (1978) The regulation of glutamate metabolism by tricarboxylic acid-cycle activity in rat brain mitochondria. Biochem $\mathrm{J}$ 172:155-162.

Derouiche A, Rauen T (1995) Coincidence of L-glutamate/L-aspartate transporter (GLAST) and glutamine synthetase (GS) immunoreactions in retinal glia: evidence for coupling of GLAST and GS in transmitter clearance. J Neurosci Res 42:131-143.

Derouiche A, Hartig W, Brauer K, Bruckner G (1996) Spatial relationship of lectin-labelled extracellular matrix and glutamine synthetaseimmunoreactive astrocytes in rat cortical forebrain regions. J Anat 189:363-72.

Do KQ, Lauer CJ, Schreiber W, Zollinger M, Gutteck-Amsler U, Cuenod M, Holsboer F (1995) gamma-Glutamylglutamine and taurine concentrations are decreased in the cerebrospinal fluid of drug-naive patients with schizophrenic disorders. J Neurochem 65:2652-2662.

Eichel HJ, Rem LT (1962) Respiratory enzyme studies in Tetrahymena pyriformis. V. Some properties of an L-lactic oxidase. J Biol Chem 237:940-945.

Elamari A, Gisin N, Munoz JL, Poitry S, Tsacopoulos M, Zbinden H (1997) Photon-counting optical-fiber sensor for the detection of ammonia in neurochemical applications. Sensors and Actuators [B] 38-39:183-188.

Eliasof S, Arriza JL, Leighton BH, Kavanaugh MP, Amara SG (1998) Excitatory amino acid transporters of the salamander retina: identification, localization, and function. J Neurosci 18:698-712.

Ernster L, Jalling O, Löw H, Lindberg O (1955) Alternative pathways of mitochondrial DPNH oxidation, studied with amytal. Exp Cell Res [Suppl]3:124-132.

Grant GB, Werblin FS (1996) A glutamate-elicited chloride current with transporter-like properties in rod photoreceptors of the tiger salamander. Vis Neurosci 13:135-144.

Haslam RJ, Krebs HA (1963) The metabolism of glutamate in homogenates and slices of brain cortex. Biochem J 88:566-578.

Hertz L, Swanson RA, Newman GC, Marrif H, Juurlink BHJ, Peng L 
(1998) Can experimental conditions explain the discrepancy over glutamate stimulation of aerobic glycolysis? Dev Neurosci 20:339-347.

Kanai Y, Hediger MA (1992) Primary structure and functional characterization of a high-affinity glutamate transporter. Nature 360:467-471.

Kanamori K, Ross BD, Kuo EL (1995) Dependence of in vivo glutamine synthetase activity on ammonia concentration in rat brain studied by $1 \mathrm{H}-15 \mathrm{~N}$ heteronuclear multiple-quantum coherence-transfer NMR. Biochem J 311:681-688.

Kapetanios AD, Poitry S, Poitry-Yamate CL, Tsacopoulos M (1998) Exposure to lactate induces rapid mitochondrial metabolic changes in solitary rods. Invest Ophthalmol Vis Sci 39:S1057.

Kar S, Arnold MA (1992) Fiber-optic ammonia sensor for measuring synaptic glutamate and extracellular ammonia. Anal Chem 64: $2438-2443$

Kikeri D, Sun A, Zeidel ML, Hebert SC (1989) Cell membranes impermeable to NH3. Nature 339:478-480.

Listrom CD, Morizono H, Rajagopal BS, McCann MT, Tuchman M, Allewell NM (1997) Expression, purification, and characterization of recombinant human glutamine synthetase. Biochem J 328:159-163.

Lowry JP, O'Neill RD, Boutelle MG, Fillenz M (1998) Continuous monitoring of extracellular glucose concentrations in the striatum of freely moving rats with an implanted glucose biosensor. J Neurochem 70:391-396.

Lowry OH, Passonneau JV (1966) Kinetic evidence for multiple binding sites on phosphofructokinase. J Biol Chem 241:2268-2279.

MacLeish PR, Townes-Anderson E (1988) Growth and synapse formation among major classes of adult salamander retinal neurons in vitro. Neuron 1:751-760.

MacLeish PR, Barnstable CJ, Townes-Anderson E (1983) Use of a monoclonal antibody as a substrate for mature neurons in vitro. Proc Natl Acad Sci USA 80:7014-7018.

Magistretti PJ, Pellerin L, Rothman DL, Shulman RG (1999) Energy on demand. Science 283:496-497.

Marcaggi P, Thwaites DT, Deitmer JW, Coles JA (1999) Chloridedependent transport of NH4+ into bee retinal glial cells. Eur J Neurosci 11:167-177.

Masters BR, Chance B (1993) Redox confocal imaging: intrinsic fluorescent probes of cellular metabolism. In: Fluorescent and luminescent probes for biological activity (Mason WT, ed), pp 44-57. New York: Academic.

McKenna MC, Sonnewald U, Huang X, Stevenson J, Zielke HR (1996) Exogenous glutamate concentration regulates the metabolic fate of glutamate in astrocytes. J Neurochem 66:386-393.

Meister A (1974) Glutamine synthetase of mammals. In: The enzymes, Ed 3, Vol 10 (Boyer PD, ed), pp 699-754. New York: Academic.

Naka K (1993) Enzyme confusion. Clin Chem 39:2351.

Pamiljans V, Krishnaswamy PR, Dumville G, Meister A (1962) Studies on the mechanism of glutamine synthesis: isolation and properties of the enzyme from sheep brain. Biochemistry 1:153-158.

Pellerin L, Magistretti PJ (1994) Glutamate uptake into astrocytes stimulates aerobic glycolysis: a mechanism coupling neuronal activity to glucose utilization. Proc Natl Acad Sci USA 91:10625-10629.

Pellerin L, Pellegri G, Martin JL, Magistretti PJ (1998) Expression of monocarboxylate transporter mRNAs in mouse brain: support for a distinct role of lactate as an energy substrate for the neonatal vs. adult brain. Proc Natl Acad Sci USA 95:3990-3995.

Poitry S, Poitry-Yamate C, Innocent C, Cosnier S, Tsacopoulos M (1997) Detection of glutamate released by neurons with an enzyme-based microelectrode: applications and limitations. Electrochim Acta 42:3217-3223.
Poitry-Yamate CL (1994) Biosynthesis, release, and possible transfer of glucose-derived carbohydrate intermediates and amino acids from mammalian glial cells to photoreceptor-neurons. PhD dissertation, University of Geneva.

Poitry-Yamate CL, Poitry S, Tsacopoulos M (1995) Lactate released by Muller glial cells is metabolized by photoreceptors from mammalian retina. J Neurosci 15:5179-5191.

Raba J, Motola HA (1994) On-line enzymatic amplification by substrate cycling in a dual bioreactor with rotation and amperometric detection. Anal Biochem 220:297-302.

Rauen T, Taylor WR, Kuhlbrodt K, Wiessner M (1998) High-affinity glutamate transporters in the rat retina: a major role of the glial glutamate transporter GLAST-1 in transmitter clearance. Cell Tissue Res 291:19-31.

Rowe WB, Ronzio RA, Meister A (1969) Inhibition of glutamine synthetase by methionine sulfoximine. Studies on methionine sulfoximine phosphate. Biochemistry 8:2674-2680.

Schousboe A, Westergaard N, Waagepetersen HS, Larsson OM, Bakken IJ, Sonnewald U (1997) Trafficking between glia and neurons of TCA cycle intermediates and related metabolites. Glia 21:99-105.

Sibson NR, Dhankhar A, Mason GF, Rothman DL, Behar KL, Shulman RG (1998) Stoichiometric coupling of brain glucose metabolism and glutamatergic neuronal activity. Proc Natl Acad Sci USA 95:316-321.

Sies H (1982) Nicotinamide nucleotide compartmentation. In: Metabolic compartmentation (Sies H, ed), pp 205-231. London: Academic.

Slater EC (1967) Application of inhibitors and uncouplers for a study of oxidative phosphorylation. Methods Enzymol 10:48-57.

Sonnewald U, Westergaard N, Schousboe A (1997) Glutamate transport and metabolism in astrocytes. Glia 21:56-63.

Townes-Anderson E, MacLeish PR, Raviola E (1985) Rod cells dissociated from mature salamander retina: ultrastructure and uptake of horseradish peroxidase. J Cell Biol 100:175-188.

Tsacopoulos M, Magistretti PJ (1996) Metabolic coupling between glia and neurons. J Neurosci 16:877-885.

Tsacopoulos M, Veuthey AL, Saravelos SG, Perrottet P, Tsoupras G (1994) Glial cells transform glucose to alanine, which fuels the neurons in the honeybee retina. J Neurosci 14:1339-1351.

Tsacopoulos M, Poitry-Yamate CL, Poitry S (1997a) Ammonium and glutamate released by neurons are signals regulating the nutritive function of a glial cell. J Neurosci 17:2383-2390.

Tsacopoulos M, Poitry-Yamate CL, Poitry S, Perrottet P, Veuthey AL (1997b) The nutritive function of glia is regulated by signals released by neurons. Glia 21:84-91.

Tsacopoulos M, Poitry-Yamate CL, MacLeish PR, Poitry S (1998) Trafficking of molecules and metabolic signals in the retina. Prog Retin Eye Res 17:429-442.

Waniewski RA (1992) Physiological levels of ammonia regulate glutamine synthesis from extracellular glutamate in astrocyte cultures. J Neurochem 58:167-174.

Westergaard N, Drejer J, Schousboe A, Sonnewald U (1996) Evaluation of the importance of transamination versus deamination in astrocytic metabolism of [U-13C]glutamate. Glia 17:160-168.

Yudkoff M (1997) Brain metabolism of branched-chain amino acids. Glia 21:92-98.

Yudkoff M, Nissim I, Hummeler K, Medow M, Pleasure D (1986) Utilization of $[15 \mathrm{~N}]$ glutamate by cultured astrocytes. Biochem J 234: 185-192. 